\title{
Elucidating modern West Antarctic sea surface conditions: An intercomparison of lipid biomarker proxies, instrumental and numerical-model data
}

Nele Lamping ${ }^{1}$, Juliane Müller ${ }^{1,2,3}$, Jens Hefter ${ }^{1}$, Gesine Mollenhauer ${ }^{1,2,3}$, Christian Haas ${ }^{1}$, Xiaoxu Shi ${ }^{1}$, Maria-Elena 5 Vorrath $^{1,4}$, Gerrit Lohmann ${ }^{1,3,5}$

${ }^{1}$ Alfred-Wegener-Institut Helmholtz-Zentrum für Polar- und Meeresforschung, Am Alten Hafen 26, 27568 Bremerhaven, Germany

${ }^{2}$ Department of Geosciences, University of Bremen, Klagenfurter Straße, 28359 Bremen, Germany

${ }^{3}$ Marum - Center for Marine Environmental Sciences, Leobener Straße 8, 28359 Bremen, Germany

$10 \quad{ }^{4}$ Laboratoire des Sciences de l'Environnement Marin (LEMAR), Université de Bretagne Occidentale, Brest, France

${ }^{5}$ Department of Environmental Physics, University of Bremen, 28359 Bremen, Germany

Correspondence to: Nele Lamping (nele.lamping@awi.de)

Abstract. The importance of Southern Ocean sea ice has come into the focus of polar research in the last couple of decades. Especially in West Antarctica, where sea ice has declined, its distribution and evolution play a critical role for the stability of nearby ice shelves. Organic geochemical analyses of marine surface sediments from the West Antarctic continental shelves permit a biomarker-based reconstruction of sea surface conditions in these vulnerable areas. We analysed highly branched isoprenoids (HBIs), such as the sea-ice proxy $\mathrm{IPSO}_{25}$ and phytoplankton-derived HBI-trienes, but also phytosterols and isoprenoidal glycerol dialkyl glycerol tetraethers (GDGTs), which are established tools for the reconstruction of primary productivity and sea surface temperatures, respectively. The combination of $\mathrm{IPSO}_{25}$ with a phytoplankton marker results in the semi-quantitative sea-ice index PIPSO $_{25}$, which provides useful reconstructions of sea-ice conditions, avoiding misleading over- or underestimations of sea-ice cover. Comparisons of the biomarker-based sea-ice distribution patterns and GDGT-based temperatures with (1) sea-ice distributions obtained from satellite observations and (2) estimated sea-ice patterns and SSTs deduced from modelled data are in reasonable agreement, but also highlight specific aspects that need to be considered when interpreting biomarker data. We further discuss $\mathrm{IPSO}_{25}$ concentrations in the vicinity of ice shelves, where elevated values could be related to the occurrence of ice shelf basal melt water and platelet ice under landfast sea ice.

\section{Introduction}

One of the key components of the global climate system, influencing major atmospheric and oceanic processes, is floating on the ocean's surface at high latitudes - sea ice (Thomas, 2017). Southern Ocean sea ice is one of the most strongly changing features of the Earth's surface as it experiences considerable seasonal variabilities with decreasing sea-ice extent from a maximum of $20 \times 10^{6} \mathrm{~km}^{2}$ in September to a minimum of $4 \times 10^{6} \mathrm{~km}^{2}$ in March (Arrigo et al., 1997; Zwally, 1983). This seasonal waxing and waning of sea ice substantially modifies deep-water formation, the ocean-atmosphere exchange of heat and gas, strongly affects surface albedo and radiation budgets (Abernathey et al., 2016; Nicholls et al., 2009; Turner et al., 2017) and also regulates ocean buoyancy flux, upwelling and primary production (Schofield et al., 2018).

Southern Ocean sea-ice extent has undergone regionally contrasting changes since the beginning of satellite-based observations in 1979 (Parkinson, 2019). In the 40-year satellite record, sea-ice extent in East Antarctica is increasing, experiencing an abrupt reversal from 2014 to 2018 (even exceeding the drastic decay rates reported in the Arctic; Comiso et al., 2017; Parkinson, 2019; Parkinson and Cavalieri, 2012). Sea-ice extent in West Antarctica, however, is decreasing since the beginning of satellite-based observations 40 years ago (Parkinson and Cavalieri, 2012). Here, the Antarctic Peninsula has been affected by significant changes in sea-ice duration over the past few decades, undergoing a strong decrease in sea-ice 
40 extent (Liu et al., 2004) and rapid atmospheric warming (Vaughan et al., 2003). The Larsen Ice Shelves A and B, located at the East Antarctic Peninsula, collapsed in 1995 and 2002, respectively, which Massom et al. (2018) linked to the loss of a seaice buffer, enabling an increased flexure of the ice shelf margins by ocean swells. The Bellingshausen and Amundsen Seas are also affected by a stark sea-ice decline (Hobbs et al., 2016; Parkinson, 2019). Glaciers draining into the Amundsen Sea are thinning at an alarming rate, which has been linked to basal melting caused by relatively warm Circumpolar Deep Water (CDW) incursions into sub-ice shelf cavities, thinning the adjacent ice shelves from below (e.g., Jacobs et al., 2011). The disintegration of ice shelves reduces the buttressing force for the West Antarctic Ice Sheet, which may lead to a partial collapse of ice shelves in these catchments, eventually impacting global sea level rise significantly (Pritchard et al., 2012; Vaughan, 2008).

State-of-the-art climate models are not yet fully able to depict sea-ice seasonality and sea-ice cover, which the $5^{\text {th }}$ Assessment

50 Report of the Intergovernmental Panel on Climate Change (Stocker et al., 2013) explains by a lack of validation efforts using proxy-based sea-ice reconstructions. Knowledge about (paleo-) sea-ice conditions in the climate sensitive areas around the West Antarctic Ice Sheet is hence considered as crucial for understanding past and future climate evolution.

To date, the most common proxy-based sea-ice reconstructions in the Southern Ocean are conducted by the use of sympagic diatom assemblages, which are strongly dependent on their preservation within the sediments (Allen et al., 2011; Armand and

55 Leventer, 2003; Crosta et al., 1998; Esper and Gersonde, 2014; Gersonde and Zielinski, 2000; Leventer, 1998). Dissolution effects within the water column or after deposition determine the preservation state of the small, lightly silicified microfossils and may alter the diatom record, leading to inaccurate sea-ice reconstructions (Leventer, 1998; Zielinski et al., 1998). To avoid ambiguous interpretations, the molecular remains of certain diatoms, specific organic geochemical lipids, have recently emerged as a robust proxy for reconstructing past (and present) Antarctic sea ice (Barbara et al., 2013; Collins et al., 2013;

60 Denis et al., 2010; Etourneau et al., 2013; Lamping et al., 2020; Massé et al., 2011; Vorrath et al., 2019; 2020). Specifically, a di-unsaturated highly branched isoprenoid (HBI) alkene (HBI diene, $\mathrm{C}_{25: 2}$ ) has been detected in both sea-ice diatoms and sediments in the Southern Ocean (Johns et al., 1999; Massé et al., 2011; Nichols et al., 1988) and the sympagic (i.e. living within sea ice) tube-dwelling diatom Berkeleya adeliensis was recently identified as producer, which preferably proliferates in platelet ice (Belt et al., 2016; Riaux-Gobin and Poulin, 2004). However, B. adeliensis seems rather flexible concerning its habitat, since it was also recorded in the bottom ice layer and seems to be well adapted to changes in texture during ice melt (Riaux-Gobin et al., 2013). Belt et al. (2016) introduced the term IPSO $_{25}$ ("Ice Proxy of the Southern Ocean with 25 carbon atoms") because of the structurally close relationship of this lipid to the counterpart $\mathrm{IP}_{25}$ in the Arctic. Hitherto, only a relatively small number of studies based on $\mathrm{IPSO}_{25}$ for recent and Holocene sea-ice reconstructions is available in the Southern Ocean (Barbara et al., 2010; 2013; Belt et al., 2016; 2018; Collins et al., 2013; Denis et al., 2010; Etourneau et al., 2013; Lamping et 70 al., 2020; Massé et al., 2011; Tesi et al., 2020; Vorrath et al., 2019; 2020). Commonly, for a more detailed assessment of seaice conditions, $\mathrm{IP}_{25}$ in the Arctic Ocean and $\mathrm{IPSO}_{25}$ in the Southern Ocean have been measured alongside complementary phytoplankton derived lipids, such as sterols and/or HBI-trienes, which are indicative of open-water conditions (Belt and Müller, 2013; Lamping et al., 2020; Müller et al., 2011; Vorrath et al., 2019; 2020). The combination of the sea-ice biomarker and a phytoplankton biomarker, the so called $\mathrm{PIP}_{25}$ index for the Arctic (Müller et al., 2011) and the PIPSO $_{25}$ index for the

75 Antarctic (Vorrath et al., 2019), allow for a more quantitative differentiation of contrasting sea-ice settings. A misinterpretation of an absent sea-ice biomarker, which can be the result of either no sea-ice cover or a severe sea-ice cover, that prevents light penetration hence limiting ice algae growth, can be circumvented with this approach.

Mechanisms contributing to ice shelf instability are manifold. As previously mentioned, relatively warm CDW is considered one of the main drivers for ice shelf thinning in the Amundsen Sea Embayment (Jacobs et al., 2011; Jenkins and Jacobs, 2008).

80 Accordingly, changing ocean temperatures are another crucial factor for the fate of West Antarctic Ice Sheet stability (e.g., Colleoni et al., 2018). As for sea-ice reconstructions, organic geochemical lipids for reconstructing past and recent ocean temperatures in high latitudes have come into focus in the past decades, since the preservation of calcium carbonate 

glycerol tetraethers (isoGDGTs), sensitive to temperature change and relatively resistant to degradation processes, are wellpreserved in marine sediments (Huguet et al., 2008; Schouten et al., 2013). Hence, isoGDGTs are considered to be valuable tools for reconstructing ocean temperatures (Schouten et al., 2002).

Our aim with this study is to provide insight into the application of biomarkers for sea ice as well as ocean temperature reconstructions. Estimates on recent sea-ice conditions along the eastern and western Antarctic Peninsula, the Amundsen and Weddell Seas, are based on the analyses of $\mathrm{IPSO}_{25}$, HBI-trienes and phytosterols in surface sediment samples from these areas. We further address the potential connection between $\mathrm{IPSO}_{25}$ and platelet ice formation under near-coastal fast ice, which is related to the presence of near-surface ice shelf basal melt water. An intercomparison of sea ice as well as temperature reconstructions (based on GDGT analyses) with (1) sea-ice distributions obtained from satellite observations and (2) estimated sea-ice distribution and SSTs deduced from modelled data provides for an evaluation of the proxy approaches. For a more semi-quantitative sea-ice estimate, the relatively new approach of $\mathrm{PIPSO}_{25}$ has been used to further assess the advantages and limitations of the sea-ice index as a potential tool to validate and improve numerical climate models to better understand current and past trends in sea-ice development in the Southern Ocean.

\section{Regional setting}

The areas of investigation in this study include the southern Drake Passage, the continental shelves of the West and East Antarctic Peninsula $\left(\sim 60^{\circ} \mathrm{S}\right)$ and the more southerly located Amundsen and Weddell Seas $\left(\sim 75^{\circ} \mathrm{S}\right.$; Fig. 1). The different study areas are all connected by the only current circumnavigating the globe, the Antarctic Circumpolar Current (ACC; Meredith et al., 2011; Rintoul et al., 2001). The ACC is the largest current system in the world characterised by a strong eastward flow, which finds its narrowest constriction in the Drake Passage. It is mainly composed of CDW, which is generally divided into the Upper CDW with low oxygen and high nutrient concentrations, and Lower CDW with high salinities (Rintoul et al., 2001). Along the Bellingshausen Sea, the Amundsen Sea and West Antarctic Peninsula (i.e., the Bransfield Strait), where the ACC flows close to the continental shelf edge, $\mathrm{CDW}$ is upwelling onto the shelf via bathymetric troughs, contributing to basal melt and retreat of the adjoining ice shelves (Jacobs et al., 2011; Jenkins and Jacobs, 2008; Klinck et al., 2004). In the Weddell Sea, where the ACC is located sufficiently far from the Antarctic continent, a subpolar cyclonic circulation is present south of the ACC, the Weddell Gyre. The Weddell Gyre is the main circulation in the Weddell Sea and the most important source of Antarctic Bottom Water (Deacon, 1979), with sea-ice formation as an important factor in generating these dense water masses (Harms et al., 2001). Wind and currents force a northward sea-ice drift in the western Weddell Sea along the coast of the East Antarctic Peninsula (Harms et al., 2001) until leaving it to melt in warmer waters to the North and up to the Powell Basin (Vernet et al., 2019). At the northern tip of the Antarctic Peninsula, Transitional Weddell Sea Water (TWW) branches off into the Bransfield Strait and is characterised by colder temperatures and higher salinities as a result of extended sea-ice formation in the Weddell Gyre (Collares et al., 2018; Thompson et al., 2009). Here, it encounters the well-stratified, warm, and fresh Bellingshausen Sea Water (BSW; Fig. 1), which is entering the Bransfield Strait from the West (Sangrà et al., 2011). Since 1978, satellite observations show strong seasonal shifts of sea-ice cover at the Antarctic Peninsula, which is less pronounced in the more southerly Amundsen and Weddell Seas (Fig. 2a-c). Mean monthly sea-ice concentrations (SIC) for winter (JJA), spring (SON) and summer (DJF) reveal a permanently ice-free Drake Passage, while the West and East Antarctic Peninsula shelf areas are influenced by a changing sea-ice cover in the course of a year (Fig. 2a-c). For the Amundsen and Weddell Seas, satellite data reveal a closed seasonal sea-ice cover with up to $\sim 90 \%$ concentration during winter and spring (Fig. $2 \mathrm{a}+\mathrm{b}$ ), and a late break-up of sea-ice cover to a minimum concentration of $\sim 30 \%$ during summer (Fig. $2 \mathrm{c}$ ). 


\section{Material and methods}

\subsection{Sediment material}

In total, we analysed a set of 41 surface sediment samples from different areas of the Southern Ocean (Fig. 1), all have been retrieved by multicorers during $R V$ Polarstern expeditions in the past years. 16 surface sediment samples from the Amundsen Sea continental shelf were collected during RV Polarstern expeditions PS69 in 2007 (Gohl, 2007) and PS104 in 2017 (Gohl, 2017). 25 surface sediment samples from the southeastern and southwestern Weddell Sea continental shelf were collected during RV Polarstern expeditions PS111 in 2018 (Schröder, 2018) and PS118 in 2019 (Dorschel, 2019). This set of samples was complemented by 26 surface sediment samples from the Bransfield Strait/West Antarctic Peninsula for which the analytical results were already published by Vorrath et al. (2019).

\subsection{Bulk sediment and organic geochemical analyses}

The sediment material was freeze-dried and homogenized with an agate mortar and stored in glass vials at $-20{ }^{\circ} \mathrm{C}$ before and after these initial preparation steps to avoid degradation of targeted molecular components. The analysis of total organic carbon (TOC) contents was conducted on $0.1 \mathrm{~g}$ of sediment after removing inorganic carbon (total inorganic carbon, carbonates) with $500 \mu 12 \mathrm{~N}$ hydrochloric acid. Measurements were conducted by means of a carbon-sulphur determinator (CS 2000; Eltra) with standards being measured for calibration before sample analyses and after every tenth sample to ensure accuracy (error \pm $0.02 \%)$.

Lipid biomarker extraction of the sediment (4 $\mathrm{g}$ for PS69 and PS104; $6 \mathrm{~g}$ for PS111 and PS118) was done by ultrasonication ( 3 x $15 \mathrm{~min}$ ), using dichloromethane:methanol ( $3 \times 6 \mathrm{ml}$ for PS69 and PS104; $3 \times 8 \mathrm{ml}$ for PS111 and PS118; 2:1 v/v) as solvent. Prior to this step, the internal standards 7-hexylnonadecane (7-HND; $20 \mu 1 /$ sample for PS69 and PS104 and 30 $\mu 1 /$ sample for PS111 and PS118), $5 \alpha$-androstan-3-ol (40 $\mu 1 /$ sample) and $\mathrm{C}_{46}(100 \mu 1 /$ sample) were added to the sample for quantification of HBIs, sterols and GDGTs, respectively. Via open-column chromatography, with $\mathrm{SiO}_{2}$ as stationary phase, fractionation of the extract was achieved by eluting the apolar fraction (HBIs) and the polar fraction (sterols and GDGTs) with

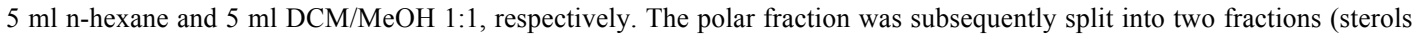
and GDGTs) for further processing. The sterol fraction was silylated with $300 \mu \mathrm{l}$ bis-trimethylsilyl-trifluoroacetamide (BSTFA; $2 \mathrm{~h}$ at $60{ }^{\circ} \mathrm{C}$ ). Compound analyses of HBIs and sterols were carried out on an Agilent Technologies 7890B gas chromatograph (GC; fitted with a $30 \mathrm{~m}$ DB $1 \mathrm{MS}$ column; $0.25 \mathrm{~mm}$ diameter and $0.25 \mu \mathrm{m}$ film thickness) coupled to an Agilent Technologies 5977B mass selective detector (MSD; with $70 \mathrm{eV}$ constant ionization potential, ion source temperature of 230 ${ }^{\circ} \mathrm{C}$ ). The GC oven was set to: $60{ }^{\circ} \mathrm{C}(3 \mathrm{~min}), 150{ }^{\circ} \mathrm{C}$ (rate: $\left.15^{\circ} \mathrm{C} / \mathrm{min}\right), 320^{\circ} \mathrm{C}$ (rate: $\left.10{ }^{\circ} \mathrm{C} / \mathrm{min}\right), 320^{\circ} \mathrm{C}(15 \mathrm{~min}$ isothermal)

150 for the analysis of hydrocarbons and to: $60^{\circ} \mathrm{C}(2 \mathrm{~min}), 150{ }^{\circ} \mathrm{C}$ (rate: $\left.15{ }^{\circ} \mathrm{C} / \mathrm{min}\right), 320{ }^{\circ} \mathrm{C}$ (rate: $\left.3{ }^{\circ} \mathrm{C} / \mathrm{min}\right), 320{ }^{\circ} \mathrm{C}(20 \mathrm{~min}$ isothermal) for the analysis of sterols. Helium was used as carrier gas. The identification of HBI and sterol compounds is based upon their GC retention times and mass spectra (Belt, 2018; Belt et al., 2000; Boon et al., 1979). Lipid quantification was obtained by setting the individual, manually integrated, GC-MS peak area in relation to the peak area of the respective internal standard and normalization to the amount of extracted sediment. Quantification of $\mathrm{IPSO}_{25}$ and $\mathrm{HBI} Z$-triene was achieved using their molecular ion (IPSO $25: \mathrm{m} / \mathrm{z} 348$ and HBI Z-triene: $\mathrm{m} / \mathrm{z} 346$ ) in relation to the fragment ion $\mathrm{m} / \mathrm{z} 266$ of the internal standard 7-HND (Belt, 2018). Quantification of sterols was achieved by comparison of the fragment ion of the individual sterol with the fragment ion $\mathrm{m} / \mathrm{z} 348$ of the internal standard $5 \alpha$-androstan-3-ol. Instrumental response factors for the target lipids were considered as recommended by Belt et al. (2014) and Fahl and Stein (2012). All biomarker concentrations were subsequently normalized to the TOC content of each sample to account for different depositional settings within the different 160 study areas.

For calculating the phytoplankton-IPSO $25\left(\mathrm{PIPSO}_{25}\right)$ index, we used the equation introduced by Vorrath et al. (2019):

$\mathrm{PIPSO}_{25}=\frac{\mathrm{IPSO}_{25}}{\left(\mathrm{IPSO}_{25}+(\text { phytoplankton marker x })\right)}$. 
where $\mathrm{c}\left(\mathrm{c}=\right.$ mean $\mathrm{IPSO}_{25} /$ mean phytoplankton marker) is applied as a concentration balance factor to account for high concentration offsets between IPSO $_{25}$ and the phytoplankton biomarker (see Table S1 for c-factors of individual PIPSO 25 calculations).

Following the approach by Müller and Stein (2014) and Lamping et al. (2020), samples with exceptionally low (at detection limit) concentrations of both biomarkers have been assigned a $\mathrm{PIPSO}_{25}$ value of 1 (see chapter 4.1.2). This accounts for five sample stations in the Weddell Sea PS111/13-2, /15-1,/16-3, /29-3; /40-2 (marked as orange x in Fig. 1).

The GDGT fraction was dried under $\mathrm{N}_{2}$, redissolved with $120 \mu \mathrm{l}$ hexane:isopropanol (v/v 99:1) and then filtered using a polytetrafluoroethylene (PTFE) filter with a $0.45 \mu \mathrm{m}$ pore sized membrane. GDGT measurements were carried out using high performance liquid chromatography (HPLC; Agilent 1200 series HPLC system) coupled to an Agilent 6120 mass spectrometer (MS), operating with atmospheric pressure chemical ionization (APCI). The injection volume was $20 \mu 1$. For separating the GDGTs, a Prevail Cyano $3 \mu \mathrm{m}$ column (Grace, $150 \mathrm{~mm} * 2.1 \mathrm{~mm}$ ) was kept at $30^{\circ} \mathrm{C}$. Each sample was eluted isocratically for $5 \mathrm{~min}$ with solvent $\mathrm{A}=$ hexane/2-propanol/chloroform; 98:1:1 at a flow rate of $0.2 \mathrm{ml} / \mathrm{min}$, then the volume of solvent $\mathrm{B}=$ hexane/2-propanol/chloroform; 89:10:1 was increased linearly to $10 \%$ within 20 min and then to $100 \%$ within 10 min. The column was back-flushed ( $5 \mathrm{~min}$, flow $0.6 \mathrm{ml} / \mathrm{min}$ ) after $7 \mathrm{~min}$ after each sample and re-equilibrated with solvent A (10 min, flow $0.2 \mathrm{ml} / \mathrm{min}$ ). The APCI was set to the following: $\mathrm{N}_{2}$ drying gas flow at $5 \mathrm{l} / \mathrm{min}$ and temperature to $350{ }^{\circ} \mathrm{C}$, nebulizer pressure to $50 \mathrm{psi}$, vaporizer gas temperature to $350^{\circ} \mathrm{C}$, capillary voltage to $4 \mathrm{kV}$ and corona current to $+5 \mu \mathrm{A}$. Detection of GDGTs was achieved by means of selective ion monitoring (SIM) of $[\mathrm{M}+\mathrm{H}]^{+}$ions (dwell time $76 \mathrm{~ms}$ ). Determination and quantification of the molecular ions of GDGT-0 ( $\mathrm{m} / \mathrm{z}$ 1302), GDGT-1 ( $\mathrm{m} / \mathrm{z} 1300)$, GDGT-2 (m/z 1298), GDGT-3 (m/z 1296) and crenarchaeol $(\mathrm{m} / \mathrm{z}$ 1292) as well as of brGDGT-III $(\mathrm{m} / \mathrm{z} 1050)$, brGDGT-II $(\mathrm{m} / \mathrm{z} 1036)$ and brGDGT-I ( $\mathrm{m} / \mathrm{z}$ 1022) was done in relation to the molecular ion $\mathrm{m} / \mathrm{z} 744$ of the internal standard $\mathrm{C}_{46}$-GDGT. The late eluting hydroxylated GDGTs (OH-GDGT0, OH-GDGT-1 and OH-GDGT-2 with $\mathrm{m} / \mathrm{z} 1318,1316$ and 1314, respectively) were quantified in the scans $(\mathrm{m} / \mathrm{z} 1300,1298$, 1296) of their related GDGTs, as described by Fietz et al. (2013). $\mathrm{TEX}^{\mathrm{L}}{ }_{86}$ values and their conversion into temperatures were determined following Kim et al. (2010):

$\mathrm{TEX}_{86}^{\mathrm{L}}=\mathrm{LOG} \frac{[\mathrm{GDGT}-2]}{[\mathrm{GDGT}-1]+[\mathrm{GDGT}-2]+[\mathrm{GDGT}-2]}$,

$\mathrm{SST}^{\mathrm{TEX}}\left[{ }^{\circ} \mathrm{C}\right]=67.5 \times \mathrm{TEX}_{86}^{\mathrm{L}}+46.9$.

Temperature calculations based on OH-GDGTs were carried out according to Lü et al. (2015):

$\mathrm{RI}-\mathrm{OH}^{\prime}=\frac{[\mathrm{OH}-\mathrm{GDGT}-1]+2 \times[\mathrm{OH}-\mathrm{GDGT}-2]}{[\mathrm{OH}-\mathrm{GDGT}-0]+[\mathrm{OH}-\mathrm{GDGT}-1]+[\mathrm{OH}-\mathrm{GDGT}-2]}$,

$\mathrm{SST}^{\mathrm{OH}}\left[{ }^{\circ} \mathrm{C}\right]=\left(\mathrm{RI}-\mathrm{OH}^{\prime}-0.1\right) / 0.0382$.

To determine the relative influence of terrestrial organic matter input, the BIT-index was calculated following Hopmans et al. (2004):

$\mathrm{BIT}=\frac{[\text { brGDGT }-\mathrm{I}]+[\text { brGDGT }-\mathrm{II}]+[\text { brGDGT }-\mathrm{III}]}{[\text { Chrenarchaeol }]+[\text { brGDGT }-\mathrm{I}]+[\text { brGDGT }-\mathrm{II}]+[\text { brGDGT }-\mathrm{III}]}$.

\subsection{Numerical model}

\subsubsection{Model description}

AWI-ESM2 is a state-of-the-art coupled climate model developed by Sidorenko et al. (2019) which comprises an atmospheric component ECHAM6 (Stevens et al., 2013) as well as an ocean-sea ice component FESOM2 (Danilov et al., 2017). The atmospheric module ECHAM6 is the most recent version of the ECHAM model developed at the Max Planck Institute for Meteorology (MPI) in Hamburg. The model is branched from an early release of the European Center (EC) for Medium Range 
with traditional approximation. We used T63 Gaussian grid which has a spatial resolution of about $1.9 \times 1.9$ degree $\left(1.9^{\circ}\right.$ or $210 \mathrm{~km})$. There are 47 vertical layers in the atmosphere.

Momentum transport arising from boundary effects is configured using the subgrid orography scheme as described by Lott (1999). Radiative transfer in ECHAM6 is represented by the method described in Iacono et al. (2008). ECHAM6 also contains

a Land-Surface Model (JSBACH) which includes 12 functional plant types of dynamic vegetation and 2 bare-surface types (Loveland et al., 2000; Raddatz et al., 2007). The ice-ocean module in AWI-ESM2 is based on the finite volume discretization formulated on unstructured meshes. The multi-resolution for the ocean is up to $15 \mathrm{~km}$ over polar and coastal regions, and 135 $\mathrm{km}$ for far-field oceans, with 46 uneven vertical depths. The impact of local dynamics on the global ocean is related to a number of FESOM-based studies (Danilov et al., 2017). The multi-resolution approach advocated by FESOM allows one to

210 explore the impact of local processes on the global ocean with moderate computational effort (Danilov et al., 2017). AWIESM2 employs the OASIS3-MCT coupler (Valcke, 2013) with an intermediate regular exchange grid. Mapping between the intermediate grid and the atmospheric/oceanic grid is handled with bilinear interpolation. The atmosphere component computes 12 air-sea fluxes based on four surface fields provided by the ocean module FESOM2. AWI-ESM2 has been validated under modern climate conditions (Sidorenko et al., 2019) and has been applied for marine radiocarbon concentrations (Lohmann et al., 2020), the latest Holocene (Vorrath et al., 2020), and the Last Interglacial (Otto-Bliesner et al., 2021).

\subsubsection{Experimental design}

One transient experiment was conducted using AWI-ESM2, which applied the boundary conditions, including orbital parameters and greenhouse gases. Orbital parameters are calculated according to Berger (1978), and the concentrations of greenhouse gases are taken from ice-core records as well as from recent measurements of firn air and atmospheric samples (Köhler et al., 2017). The model was initialized from a 1,000-year spin-up run under mid-Holocene boundary conditions as described (Otto-Bliesner et al., 2017). In our modeling strategy, we follow Lorenz and Lohmann (2004) and use the climate condition from the preindustrial state as spin-up and initial state for the subsequent transient simulation covering the period 1950-2014 CE. Topography including prescribed ice sheet was kept constant in our transient simulation. All model data are provided in Table S2.

\subsection{Satellite SIC and SSTs}

Satellite data are derived from Nimbus-7 SMMR and DMSP SSM/I-SSMIS passive microwave data and downloaded from the National Snow and Ice Data Center (NSIDC; Cavalieri et al., 1996). The sea-ice data represent mean monthly SIC, which are expressed to range from $0 \%$ to $100 \%$ and are averaged over a period of the beginning of satellite observations in 1978 to the individual year of sample retrieval. The monthly mean SIC were then split into different seasons: winter (JJF), spring (SON) and summer (DJF) (Fig. 2a-c) and the data are considered to represent the recent mean state of sea-ice coverage. All satellite data are provided in Table S3.

Modern annual mean SSTs are derived from the World Ocean Atlas 13 representing averaged values for the years 1955-2012 (Fig. 5c; WOA13; Locarnini et al., 2013).

\section{Results and discussion}

\subsection{Environmental settings of the Southern Ocean depicted by proxy data}

In the following, we describe the biomarker and model data assembled during this study from North (Antarctic Peninsula) to South (Amundsen and Weddell Seas) and draw conclusions about the environmental settings deduced from the data set. All biomarker data collected during this study are provided in Table S1 and are available via the PANGAEA data repository (in prep.). 


\subsubsection{TOC content, HBIs and sterols in Antarctic surface sediments}

TOC contents in marine sediments in a first approximation are often viewed as an indicator for primary productivity in surface waters (Meyers, 1997), however we are aware that additional factors, such as different water depths or depositional regimes, may exert control on sedimentary TOC as well. The TOC contents of the herein investigated surface samples are lowest in the Drake Passage with values around 0.12-0.54 \%, increasing in a northwest-southeast gradient into the Bransfield Strait, ranging between 0.59-1.06 \% (Fig. 3a; WAP).

At the East Antarctic Peninsula, higher TOC contents (0.57-0.86 \%) prevail around the Larsen Ice Shelf with a decreasing trend towards the Powell Basin (0.22-0.37\%) and an increase to $0.50 \%$ around the area of the South Orkney Islands, pointing to elevated productivity in these areas (Fig. 3a; EAP). The elevated TOC contents in this area may, however, also be attributable to higher inputs of reworked terrigenous organic matter.

250 At the West Antarctic Peninsula, concentrations of the sea-ice biomarker IPSO$_{25}$ show a northwest-southeast gradient with $\mathrm{IPSO}_{25}$ being absent in samples from the permanently ice-free Drake Passage and increasing concentrations towards the continental slope and the seasonally ice-covered continental shelf $\left(0.37-17.81 \mu \mathrm{g}^{*} \mathrm{~g} \mathrm{OC}^{-1}\right.$; Fig. 3b; Vorrath et al., 2019). Highest $\mathrm{IPSO}_{25}$ concentrations are observed in samples of the northern Bransfield Strait affected by TWW inflow through the Antarctic Sound and along the Antarctic Peninsula which frequently exports sea ice from the Weddell Sea into the Bransfield Strait (Vorrath et al., 2019). High IPSO $_{25}$ concentrations are also observed at the East Antarctic Peninsula, influenced by a seasonal sea-ice cover, where relatively higher concentrations of the sea-ice biomarker prevail in those samples located in front of the Larsen Ice Shelf (12.59-17.74 $\mu \mathrm{g}^{*} \mathrm{~g} \mathrm{OC}{ }^{-1}$; Fig. 3b). As these locations are also influenced by the northward drift of sea ice by the Weddell Gyre (Fig. 1), the elevated $\mathrm{IPSO}_{25}$ concentrations could also result from sea ice advected from the southern Weddell Sea. We suggest that the decreasing IPSO $_{25}$ concentrations towards the Powell Basin and the South Orkney Islands (0.59-5.36 $\mu^{*} \mathrm{~g} \mathrm{OC}^{-1}$; Fig. 3b) can be connected to the warmer ocean temperatures towards the North and increased sea-ice melt during spring and summer.

Concentrations of the phytoplankton biomarker HBI Z-triene around the Antarctic Peninsula are highest in the eastern Drake Passage and along the continental slope (where $\mathrm{IPSO}_{25}$ is absent) and with lower concentrations in the Bransfield Strait (0.33$26.86 \mu \mathrm{g}^{*} \mathrm{~g} \mathrm{OC}^{-1}$; Fig. 3c; Vorrath et al., 2019). Elevated HBI Z-triene concentrations have thus far been detected in surface waters along an ice edge (Smik et al., 2016) and hence suggested to be a proxy for MIZ conditions (Belt et al., 2015; Collins et al., 2013; Schmidt et al., 2018). Vorrath et al. (2019), however, relate the high concentrations of HBI Z-triene at the northernmost stations in the permanently ice-free eastern Drake Passage to their proximity to the Antarctic Polar Front. Here, productivity of the source diatoms of HBI-trienes may be enhanced by meander-induced upwelling leading to increased nutrient flux to surface waters (Moore and Abbott, 2002). Moderate concentrations along the continental slope of the West Antarctic Peninsula and in the Bransfield Strait have been associated with elevated inflow of warm BSW which lead to a retreating sea-ice margin during spring and summer (for more details, see Vorrath et al. (2019) and Vorrath et al. (2020). Samples from the East Antarctic Peninsula continental shelf and the Powell Basin are characterised by relatively low concentrations of HBI Z-triene (Fig. 3c; where IPSO $_{25}$ concentrations are highest; 0.1-2.37 $\mu g^{*}$ g OC ${ }^{-1}$; Fig. 3b), showing a southwest-northeast gradient, while the northernmost sample closest to the South Orkney Islands is characterized by higher HBI Z-triene concentration of $\sim 8.49 \mu \mathrm{g}^{*} \mathrm{~g} \mathrm{OC}{ }^{-1}$ (Fig. 3c; EAP). This relatively high concentration may be related to an "Island Mass Effect", coined by Doty and Oguri (1956), which refers to an increased primary production around oceanic islands in comparison to surrounding waters. Nolting et al. (1991) found extraordinarily high dissolved iron levels (as high as 50-60 nM) on the shelf of the South Orkney Islands and Nielsdóttir et al. (2012) also observed enhanced iron and Chl $a$ concentrations in the vicinity of the South Orkney Islands. They connect, among others, the increased iron levels with input from seasonally retreating sea ice, which is recorded by satellites (Fig. 2a-c) and leads to a substantial annual phytoplankton bloom, which may also cause the elevated TOC contents in that sample (Fig. 3a). We assume that these conditions are favourable for the growth of the source diatoms of HBI Z-triene, leading to elevated concentrations. In the Drake Passage and the East Antarctic 
Peninsula, brassicasterol displays a similar pattern as the HBI Z-triene, with relatively higher concentrations (more than 2 magnitudes) ranging between 1.86 and $5017.44 \mu \mathrm{g}^{*} \mathrm{~g} \mathrm{OC}{ }^{-1}$ (Fig. 3d). In the sample closest to the South Orkney Islands, however, brassicasterol concentrations are not elevated, unlike the HBI Z-triene (Fig. 3d; EAP), which could refer to different environmental preferences of the source organisms producing the individual biomarkers.

In the Weddell Sea, TOC contents are generally lower (<0.4\%), with slightly elevated values in the West (up to $0.50 \%$ ) and right in front of the Filchner Ice Shelf (up to $0.52 \%$ ) (Fig. 3a). The Amundsen Sea is characterized by slightly higher TOC contents, with concentrations of up to $0.91 \%$ in the West and lower values in the East ( $0.33 \%$; Fig. 3a; AS).

In the samples from the Amundsen and Weddell Seas, dominated by a strong winter sea-ice cover lasting until spring (Fig. 2ac), all three biomarkers are low concentrated. An exception can be observed in samples from right in front of the Filchner Ice Shelf with significantly higher concentrations of $\mathrm{IPSO}_{25}\left(7.09-73.87 \mu \mathrm{g}^{*} \mathrm{~g} \mathrm{OC}^{-1}\right.$; Fig. 3b; WS). Concentrations of IPSO ${ }_{25}$ on the Amundsen Sea shelf are relatively low $\left(0.04-3.3 \mu \mathrm{g}^{*} \mathrm{~g} \mathrm{OC}^{-1}\right)$ with slightly higher values towards the north-east (Fig. 3b; AS). HBI Z-triene is also very low concentrated, showing slightly higher concentrations within the Filchner Trough (0.04-1

$\left.295 \mu \mathrm{g}^{*} \mathrm{~g} \mathrm{OC}^{-1}\right)$ and towards the more distal locations in the northeast of the Amundsen Sea $\left(0.01-1.88 \mu \mathrm{g}^{*} \mathrm{~g} \mathrm{OC}{ }^{-1}\right.$; Fig. $\left.3 \mathrm{c}\right)$. Brassicasterol generally shows similar patterns as the HBI Z-triene, with concentrations ranging between 1.86 and 220.54 $\mu \mathrm{g}^{*} \mathrm{~g} \mathrm{OC}^{-1}$ (Fig. 3d; for HBI E-triene and dinosterol distribution, see Fig. S1).

\subsubsection{Combining individual biomarker records: the $\mathrm{PIPSO}_{25}$ index}

Targeting at a more quantitative assessment of sea-ice conditions, Vorrath et al. (2019) have followed the PIP $_{25}$ index applied in the Arctic (Belt and Müller, 2013; Müller et al., 2011; Xiao et al., 2015) and introduced an equivalent sea-ice index for the Southern Ocean: $\mathrm{PIPSO}_{25}$. The $\mathrm{PIPSO}_{25}$ index combines the relative concentrations of the sea-ice biomarker $\mathrm{IPSO}_{25}$ with a selected phytoplankton biomarker (P), such as HBI-trienes and sterols, as indicator for an open-ocean environment (Vorrath et al., 2019). The combination of both end members (sea ice vs. open-ocean) prevents misleading interpretations regarding the absence of $\mathrm{IPSO}_{25}$ in the sediments, which can be the result of two entirely different scenarios. At heavy/perennial sea-ice conditions, the thickness of sea ice hinders light penetration, thereby limiting the productivity of bottom sea-ice algae (Hancke et al., 2018). This scenario may result in the absence of both phytoplankton and sea-ice biomarkers in the sediment. The other scenario is dominated by a permanently open ocean, where the sea-ice biomarker is absent as well, but here, the phytoplankton biomarkers are present in variable concentrations (Müller et al., 2011). The presence of both biomarkers in the sediment is indicative of seasonal sea-ice coverage and/or the occurrence of stable ice margin conditions, promoting biosynthesis of both biomarkers (Müller et al., 2011). We here distinguish between $\mathrm{P}_{Z} \mathrm{IPSO}_{25}$ and $\mathrm{P}_{\mathrm{B}} \mathrm{IPSO}_{25}$ using HBI Z-triene and brassicasterol as phytoplankton biomarker, respectively (Fig. 4; for $\mathrm{PIPSO}_{25}$ values based on HBI E-triene and dinosterol see Table S1 and Fig. S2).

Both $\mathrm{PIPSO}_{25}$ indices are 0 in the predominantly ice-free Drake Passage and display a northwest-southeast gradient to

315 intermediate values towards the continental slope and the South Shetland Islands, reflecting increased influence of marginal sea-ice cover towards the coast (0.02-0.70; Vorrath et al., 2019). At the seasonally sea-ice influenced East Antarctic Peninsula, $\mathrm{P}_{\mathrm{Z}} \mathrm{IPSO}_{25}$ values reach 0.84, while lower values of around 0.25 are observed close to the South Orkney Islands, which relates to the elevated HBI Z-triene concentrations at that station (Fig. 3c; EAP). The $\mathrm{P}_{\mathrm{B}} \mathrm{IPSO}_{25}$ index, however, reveals even higher values at the East Antarctic Peninsula/northwestern Weddell Sea of up to 0.98 with no elevated values towards the South Orkney Islands. These elevated $\mathrm{PIPSO}_{25}$ indices align well with the significant northward ice-drift in that region by the Weddell Gyre, which leads to high proximal sea-ice coverage at the East Antarctic Peninsula.

In samples from the southern Weddell Sea, both $\mathrm{PIPSO}_{25}$ indices show a similar pattern with high values up to 0.9 , and slightly lower values in front of the Brunt Ice Shelf (0.6; Fig. 4). Very low concentrations (close to detection limit) of both biomarkers in samples located on the continental shelf off Dronning Maud Land (Fig. 1) result in low PIPSO $_{25}$ values, strongly 

influenced by a severe seasonal sea-ice cover. As previously mentioned, we followed the approach by Müller and Stein (2014) and Lamping et al. (2020) and assigned a maximum PIPSO $_{25}$ value of 1 to these samples to circumvent misleading interpretations and aid visualisation.

Interestingly, we obtained an intermediate $\mathrm{PIPSO}_{25}$ value $(\sim 0.51)$ derived for one sample in front of the Brunt Ice Shelf, which may be indicative of a less severe sea-ice cover in that area. A possible explanation for the relatively lower $\mathrm{PIPSO}_{25}$ value may be the presence of a coastal polynya that has been reported by Anderson (1993) and which is further supported by Paul et al. (2015), who note that the sea-ice areas around the Brunt Ice Shelf is the most active in the southern Weddell Sea, with an annual average polynya area of $3516 \pm 1420 \mathrm{~km}^{2}$. The reduced SIC here are also captured by our model, which is further described in Sect. 4.1.4.

$\mathrm{PIPSO}_{25}$ values in the Amundsen Sea point to different scenarios. While the $\mathrm{P}_{Z} \mathrm{IPSO}_{25}$ index ranges around 0.9 with a slight decrease to a value of 0.3 in the easterly, more distal location (Fig. 4a), the $\mathrm{P}_{\mathrm{B}} \mathrm{IPSO}_{25}$ index is generally lower, ranging around 0.6 in the coastal area and with a much steeper decline towards distal locations to 0.2 (Fig. 4b). This difference between $\mathrm{P}_{\mathrm{Z}} \mathrm{IPSO}_{25}$ and $\mathrm{P}_{\mathrm{B}} \mathrm{IPSO}_{25}$ may be explained by the different source organisms biosynthesizing the individual phytoplankton biomarkers. While the main origin of HBI-trienes seems to be restricted to diatoms (Belt et al., 2017), brassicasterol is known to be produced by several algal groups adapted to a wider range of sea surface conditions, such as dinoflagellates, diatoms, haptophytes, among others (Volkman, 2006).

\subsubsection{TEX $^{\mathrm{L}}{ }_{86}$ - and RI-OH' - derived temperatures}

Isoprenoidal GDGTs are archaeal membrane lipid-derived proxies and valuable tools for reconstructing ocean temperatures (Schouten et al., 2002). These specific lipids, preserved in marine sediments, are sensitive to temperature change and relatively resistant to degradation processes (Huguet et al., 2008; Schouten et al., 2013). Schouten et al. (2002) found that the number of cyclopentane rings in sedimentary GDGTs is correlated with surface water temperatures and developed the first archaeal lipid paleothermometer $\mathrm{TEX}_{86}$, a ratio of certain GDGTs, as a sea surface temperature (SST) proxy.

For a critical appraisal of the applicability and reliability of GDGT indices as temperature proxies in our investigated regions, we here make use of two temperature proxy approaches developed for the high latitude polar oceans: The $\operatorname{TEX}^{\mathrm{L}}{ }_{86} \operatorname{proxy}_{\text {by }}$ Kim et al. (2010) and the RI-OH' proxy by Lü et al. (2015), calculated and calibrated using Eq. 3 and 5, respectively. The reconstructions represent annual mean ocean temperatures. In all samples, the BIT-index (Eq. 6) is $<0.3$, indicating no significant contribution of terrestrial input influencing the distribution and hence applicability of GDGTs to estimate ocean temperatures. $\mathrm{TEX}_{86}^{\mathrm{L}}$ and RI-OH' both show a similar pattern, but different temperatures, ranging between -4.23 to +10.57 ${ }^{\circ} \mathrm{C}$ and -2.62 to $+4.67{ }^{\circ} \mathrm{C}$, respectively (Fig. 5a+b). At the West Antarctic Peninsula, temperatures follow a northwest-southeast gradient with relatively higher temperatures in the permanently ice-free Drake Passage and the continental slope, influenced by the ACC and relatively warm CDW (Orsi et al., 1995; Rintoul et al., 2001). Temperatures decrease towards the Bransfield Strait and the East Antarctic Peninsula, which are influenced by a seasonal sea-ice cover and the relatively colder and highly saline TWW, branching off the Weddell Gyre (Collares et al., 2018; Thompson et al., 2009). At the East Antarctic Peninsula, a southwest-northeast gradient can be observed with relatively lower temperatures around the Larsen Ice Shelf and higher temperatures towards the Powell Basin and the South Orkney Islands, towards the North. These general temperature patterns align well with the decreasing sea-ice cover in that area towards the North.

Absolute temperature estimates derived from the two paleothermometers show significantly different ranges. While the $\mathrm{TEX}_{86}^{\mathrm{L}}$ signal is reflecting temperatures in the Amundsen and Weddell Seas quite well, it seems to be significantly warm-biased further to the North, in the Drake Passage, with up to $\sim 1{ }^{\circ} \mathrm{C}$. This warm-biased $\mathrm{TEX}_{86}^{\mathrm{L}}$ signal is a known caveat in that area and is, among others, assumed to be connected to GDGTs produced by deep-dwelling Euryarchaeota (Park et al., 2019), which have been reported in CDW (Alonso-Sáez et al., 2011) and in deep waters of the Antarctic Polar Front (López-García et al., 2001). 

warmer Drake Passage but depict temperatures in the colder regions (Amundsen and Weddell Seas) reasonably well or only slightly warm-biased, if compared to the WOA13 temperatures (Fig. 5c).

Further to the South, in the Amundsen and Weddell Seas, temperatures are generally lower than at the Antarctic Peninsula. Samples from the Weddell Sea record a temperature decrease from east to west, which may reflect an eddy-driven route in the north-eastern corner of the Weddell Gyre carrying relatively warm, salty CDW, which then advects westward along the southern edge of the Weddell Gyre (Vernet et al., 2019). While the origin of GDGTs is not yet fully understood and still debated (Ho et al., 2014), the biosynthesis of intact polar lipid GDGTs in CDW, as just recently suggested by Spencer-Jones et al. (2020), might, however, support the hypothesis of advected CDW in that area. In the Amundsen Sea, relatively higher temperatures $\left(\sim 0.5^{\circ} \mathrm{C}\right)$ at the sample locations in the north-eastern part of the embayment are reflected in the RI-OH'-derived temperatures but are not reflected in the $\mathrm{TEX}_{86}^{\mathrm{L}}$-based reconstruction.

\subsubsection{Modelled SIC and SSTs}

The global climate model setup AWI-ESM2 was used to simulate SSTs and SIC in the study area for modern conditions (1951-

2014; Fig. 5d and 6, respectively). Modelled SIC indicate an absence of sea ice in the permanently ice-free Drake Passage (Fig. 6a-c) and a northwest-southeast gradient from the continental slope to the Bransfield Strait during winter and spring (Fig. $6 \mathrm{a}+\mathrm{b})$ with the latter as being ice-free during summer (Fig. 6c). During all three seasons (from winter through spring and summer), a southwest-northeast gradient at the East Antarctic Peninsula can be observed, highlighting the decreasing sea-ice influence towards the Powell Basin in the North. Absolute modelled SIC are decreasing from winter to summer, but still underestimate SIC observed by satellites (Fig. 2). In the Amundsen and Weddell Seas, the model shows a heavy sea-ice cover $(\sim 90 \%)$ during winter and spring. Interestingly, modelled SIC in the area in front of the Brunt Ice Shelf are as low as $\sim 45 \%$ (Fig. $6 \mathrm{a}+\mathrm{b}$ ), corresponding well with the reduced $\mathrm{PIPSO}_{25}$ value of $\sim 0.51 \%$ and may reflect the polynya conditions in that region documented by Anderson (1993) and Paul et al. (2015). During summer, the model suggests a reduction in SIC in the Amundsen and Weddell Seas to about 15-25\% (Fig. 6c), slightly underestimating the satellite observations.

Modelled annual mean SSTs (Fig. 5d) are highest with up to $5{ }^{\circ} \mathrm{C}$ in the permanently ice-free Drake Passage, influenced by the relatively warm ACC. Decreasing temperatures are simulated towards the continental slope and the Bransfield Strait $(\sim$ 0.5-1 ${ }^{\circ} \mathrm{C}$ ), coinciding with the intensifying influence of sea-ice cover in that area. At the East Antarctic Peninsula/northwestern Weddell Sea, the modelled SSTs show a southwest-northeast gradient towards the Powell Basin with temperatures increasing from $-0.5{ }^{\circ} \mathrm{C}$ in the South to $0.5^{\circ} \mathrm{C}$ in the North, aligning well with the other modelled records. In the Amundsen and Weddell Seas, annual mean SSTs are negative, with temperatures from -0.5 to $-1{ }^{\circ} \mathrm{C} .5$

\section{Comparing biomarker data with satellite and numerical model data}

Here, we discuss the advantages and caveats of the sea-ice biomarker IPSO $_{25}$ and the semi-quantitative sea-ice index PIPSO 25 by comparing the proxy data to satellite and numerical model data. The main ice algae bloom in the Southern Ocean occurs during spring, when temperatures increase, sea ice starts melting, which results in the release of nutrients and stratification of the water column and the increasing solar insulation stimulates the productivity of photosynthesizing organisms (Arrigo, 2017; Belt, 2018). The sea-ice biomarker $\mathrm{IPSO}_{25}$ is hence commonly interpreted as a spring sea-ice indicator, which is why, in the following, we compare the biomarker-based sea-ice reconstructions to satellite-derived spring SIC and modelled spring SIC.

\subsection{Comparison of proxy-based, modelled and observed sea-ice conditions}

Our satellite-derived SIC represent monthly mean (spring) SIC averaged from 1978 to the individual year of sample retrieval.

The herein modelled spring SIC cover a period from 1951 to 2014 . When comparing sea-ice conditions estimated from 
sedimentary biomarker data (easily spanning decades to centuries, depending on sedimentation rates) with sea-ice conditions recorded by satellite observations (spanning $\sim 40$ years), and with modelled sea-ice conditions (spanning 63 years) the different time periods covered by the different methods need to be considered and kept in mind when interpreting the results. Vorrath et al. (2019) conducted radiocarbon dating on selected surface sediment samples from the Bransfield Strait, concluding that their biomarker data reflect the past two centuries. We hence note that biomarker data from the Antarctic Peninsula, which is affected by a very recent ice loss, may hence overestimate the sea-ice cover and underestimate ocean temperatures. Nonetheless we here correlate the biomarker data with satellite and model data to further investigate the quantitative significance of the sea ice proxy (Fig. 7). Following Esper and Gersonde (2014), who, assuming a non-linear response of sea-ice diatom productivity to sea-ice dynamics, propose the usage of a polynomial regression instead of a linear correlation, we here use a polynomial

415 regression (third degree).

$\mathrm{IPSO}_{25}$ concentrations in the surface sediments around the Antarctic Peninsula exhibit similar trends as the satellite-derived and modelled SIC, while they differ significantly in the Amundsen and Weddell Seas, where high SIC are revealed by satellites and the model but $\mathrm{IPSO}_{25}$ is very low concentrated. The relatively low $\mathrm{IPSO}_{25}$ concentrations in these areas highlight the uncertainty when considering $\mathrm{IPSO}_{25}$ as a sea-ice proxy alone, since such low concentrations are not only observed under open water conditions, but also under a severe sea-ice cover. In this case, the low concentrations of $\mathrm{IPSO}_{25}$ are the result of the latter, where limited light availability hinders ice algae growth, leading to an underestimation of sea-ice cover. As a result, $\mathrm{IPSO}_{25}$ and satellite/model data show low correlations $\left(\mathrm{R}^{2}=0.19 / \mathrm{R}^{2}=0.16\right.$; Fig. $\left.7 \mathrm{a}+\mathrm{c}\right)$, requiring caution when interpreting $\mathrm{IPSO}_{25}$ as a sea-ice proxy alone. As stated in earlier sections, the combination of $\mathrm{IPSO}_{25}$ and a phytoplankton marker may prevent this ambiguity. The perennial sea-ice cover in the Amundsen and Weddell Seas is better represented by the $\mathrm{P}_{Z} \mathrm{IPSO}_{25}$ values than by the sea-ice proxy alone. However, we note that at the southern sampling sites, the $\mathrm{PIPSO}_{25}$ index may not be able to further resolve/detail sea-ice concentrations higher than $50 \%$ reasonably well (see Fig. S3). This may be an indicator for a threshold (here $\sim 50 \% \mathrm{SIC}$ ) where the growth of the $\mathrm{HBI}$ triene and $\mathrm{IPSO}_{25}$ producing algae is limited.

In general, however, the $\mathrm{P}_{Z} I P S O_{25}$ values correlate much better with satellite/modelled $\operatorname{SIC}\left(\mathrm{R}^{2}=0.78 / \mathrm{R}^{2}=0.76\right.$; Fig. $\left.7 \mathrm{~b}+\mathrm{d}\right)$ than $\mathrm{IPSO}_{25}$ concentrations. For correlations of satellite/model data with $\mathrm{PIPSO}_{25}$ calculated using the HBI E-triene, brassicasterol and dinosterol, respectively, we refer the reader to Fig. S4. There are, however, also limitations in the semiquantitative sea-ice index $\mathrm{PIPSO}_{25}$, that need to be considered when interpreting this approach. A drawback may appear when the concentrations of the sea-ice proxy IPSO $_{25}$ and the phytoplankton marker are both low (due to unfavourable conditions for both ice algae as well as phytoplankton) or high (due to a significant seasonal shift in sea-ice cover and/or stable ice edge conditions), which may lead to similar PIPSO $_{25}$ values, although the sea-ice conditions are completely different from each other. This scenario was detected in five samples from the Weddell Sea (PS111/13-2, /15-1, /16-3, /29-3; /40-2; Fig. 3b+c), where $\mathrm{IPSO}_{25}$ and the $\mathrm{HBI} Z$-triene concentrations are close to the detection limit, while $\mathrm{P}_{\mathrm{Z}} \mathrm{IPSO}_{25}$ values are very low, suggesting a reduced sea-ice cover. Satellite and model data, however, show that these sample locations are influenced by heavy, perennial sea-ice conditions. We conclude that biomarker concentrations of both biomarkers at or close to the detection limit, indicative of a severe ice cover, need to be treated with caution. As mentioned above, we assigned a maximum $\mathrm{P}_{Z} \mathrm{IPSO}_{25}$ value of 1 to these samples and we note that such practice always needs to be made clear when applying the PIPSO $_{25}$ approach. The coupling of $\mathrm{IPSO}_{25}$ with a phytoplankton marker, nonetheless, provides the more robust and reliable sea-ice reconstructions. Regarding the above-mentioned ambiguities, we recommend to not only calculate the $\mathrm{PIPSO}_{25}$ index, but also consider individual biomarker concentrations and, if possible, take other sea-ice measures, such as satellite data and/or wellpreserved diatom assemblage data (Lamping et al., 2020; Vorrath et al., 2019; 2020) into account.

\subsection{Temperature reconstructions}

Concerning the different time frames covered by the proxy data and instrumental observations, caution must be taken when comparing GDGT-derived ocean temperature reconstructions (spanning decades to centuries) with modelled SSTs (spanning 
$\sim 63$ years) and modern SSTs based on the WOA13 (covering the time period from 1955-2012; 57 years). Since it is still not fully understood whether GDGT-based temperature reconstructions represent SSTs, near-surface or sub-surface ocean temperatures (Kalanetra et al., 2009; Kim et al., 2012; Park et al., 2019) we here refer to ocean temperatures.

GDGT-derived temperatures, annual mean SSTs (depicted by the WOA13) and modelled annual mean SSTs (Fig. 5a-d) show similar patterns at the Antarctic Peninsula and the Amundsen and Weddell Seas. $\mathrm{TEX}^{\mathrm{L}}{ }_{86}$ values correlate reasonably well with modelled annual mean SSTs $\left(\mathrm{R}^{2}=0.71\right.$; Fig. 8a). Following Park et al. (2019), stating that $\mathrm{TEX}_{86}^{\mathrm{L}}$ values in the Southern Ocean have a polynomial correlation with modern annual SSTs, we here also used a polynomial correlation. As mentioned in Sect. 4.1.3, the temperatures are, however, significantly warm-biased (up to $\sim{ }^{\circ} \mathrm{C}$ higher), which may speculatively be attributable to GDGT contributions of Euryarchaeota in CDW of the Antarctic Polar Front (Park et al., 2019). These findings are supported by a study by Spencer-Jones et al. (2020) in review, who found that GDGTs may be actively synthesized at CDW depths in the Amundsen Sea. They may hence be a significant source of isoprenoidal GDGTs within the sediments in that area.

The correlation with RI-OH'-derived temperatures is slightly lower $\left(\mathrm{R}^{2}=0.46\right.$; Fig. $\left.8 \mathrm{~b}\right)$, the temperature ranges of RI-OH' are, however, much more realistic (from -3 to $5{ }^{\circ} \mathrm{C}$ ), supporting the study by Park et al. (2019). The addition of OH-isoGDGTs in the temperature index is a promising step towards high latitude temperature reconstructions and may improve our understanding of the temperature responses of archaeal membranes in Southern Ocean waters (Fietz et al., 2020; Park et al., 2019). Clearly, more data - ideally obtained from sediment traps, surface samples as well as longer sediment cores - and calibration studies will help to further elucidate the applicability of this approach.

\section{The role of platelet ice for $\mathrm{IPSO}_{25}$ production}

Platelet ice formation plays an important role in sea-ice generation along some coastal regions of Antarctica (Hoppmann et al., 2015; 2020; Lange et al., 1989; Langhorne et al., 2015). In these regions, High Saline Shelf Water (HSSW) flows into sub-ice shelf cavities of Antarctica's continental shelves, initiating basal melt of the adjacent ice shelves (Fig. 9). The surrounding water is cooled and freshened and is then transported towards the surface, where the pressure relief can cause this water, called Ice Shelf Water (ISW), to be supercooled (Foldvik and Kvinge, 1974). The temperature of the supercooled ISW is potentially below the in-situ freezing point, which may eventually cause the formation of ice platelets that accumulate under landfast ice attached to adjacent ice shelves (Fig. 9; Holland et al., 2007; Hoppmann et al., 2015; 2020).

The sympagic, tube-dwelling, diatom B. adeliensis is a common constituent of Antarctic sea ice, preferably flourishing in the relatively open channels of sub-ice platelet layers in near-shore locations covered by fast ice (Medlin, 1990; Riaux-Gobin and Poulin, 2004). Based on investigations of sea-ice samples from the Southern Ocean, Belt et al. (2016) detected this diatom species to be a source of the HBI diene $\mathrm{IPSO}_{25}$, which, according to its habitat, led to the assumption of the sea-ice proxy being a potential indicator for the presence of platelet ice. As stated above, B. adeliensis is not confined to platelet ice, but is also observed in bottom ice and described as well adapted to changes in the texture of sea ice during ice melt (Riaux-Gobin et al., 2013).

In an attempt to elucidate the relationship of $\mathrm{IPSO}_{25}$ and platelet ice more clearly, we here regard our data in connection to observed platelet ice occurrences.

Elevated $\mathrm{IPSO}_{25}$ concentrations in front of the Larsen Ice Shelves at the East Antarctic Peninsula could be linked to several processes. So far, it is hard to differentiate between in-situ $\mathrm{IPSO}_{25}$ production or allochthonous input of IPSO $\mathrm{O}_{25}$ from drift ice. According to Langhorne et al. (2015), sea-ice cores retrieved from that area did not incorporate platelet ice. The high IPSO$_{25}$ concentrations could hence be explicable by either drift ice by the Weddell Gyre or by bottom ice production. We do, however, note that our samples reflect much longer time frames than the sea-ice samples investigated by Langhorne et al. (2015). The 
lack of platelet ice observed in their investigated sea-ice cores does not rule out the former presence of platelet ice, which may be captured in our investigated sediment samples, covering a much longer time interval.

There are several previous studies on IPSO $_{25}$ which report a close connection of the proxy to proximal, coastal locations and polynyas in the seasonal ice zone (i.e., Collins et al., 2013; Smik et al., 2016). They do not, however, discuss the relation to adjacent ice shelves as possible "platelet ice factories". We note that the core locations investigated by Smik et al. (2016) are in the vicinity of the Moscow University Ice Shelf, where Langhorne et al. (2015) did not observe platelet ice within sea-ice cores. Hoppmann et al. (2020), however, report on a sea-ice core from that area, incorporating platelet ice. The different observations by Langhorne et al. (2015) and Hoppmann et al. (2020) show how variable the occurrence of platelet ice can be. The absence of $\mathrm{IPSO}_{25}$ in the Amundsen Sea (Fig. 3b; AS) might in turn be explicable by the absence of platelet ice in that region. The Amundsen Sea shelf is classified as a warm shelf (Thompson et al., 2018) and characterized by the upwelling of warm CDW (Schmidtko et al., 2014), hindering the formation of ISW and making the presence of platelet ice in recent conditions highly unlikely (Hoppmann et al., 2020). This theory is also supported by Langhorne et al. (2015), stating that platelet ice formation is not observed, where thinning from basal melting of ice shelves is believed to be greatest, which applies to the warm shelf of the Amundsen Sea (Thompson et al., 2018). Accordingly, if the formation and accumulation of platelet ice - up to a certain degree - is indicative of basal ice shelf melting on fresh shelves (Hoppmann et al., 2015; Thompson et al., 2018), high $\mathrm{IPSO}_{25}$ concentrations determined in marine sediments may hence serve as indicator of past basal melting processes and associated ice shelf dynamics. This may, however, only be true up to a certain threshold where platelet ice

505 formation is diminished/hampered due to warm oceanic conditions leading to a too intense basal melting (Langhorne et al., 2015).

While using $\mathrm{IPSO}_{25}$ as a sea-ice proxy in Antarctica, it is hence important to also consider regional platelet ice formation processes as these may affect the $\mathrm{IPSO}_{25}$ budget. Determining thresholds associated with platelet ice formation is challenging, therefore, further investigations, such as in-situ measurements of $\mathrm{IPSO}_{25}$ concentrations in platelet ice or culture experiments

510 in home laboratories are needed to better depict the connection between $\mathrm{IPSO}_{25}$ and platelet ice formation (and ice shelf basal melting).

\section{Conclusion}

Biomarker analyses focusing on $\mathrm{IPSO}_{25}$, HBI-trienes, phytosterols and GDGTs, in surface sediment samples from the continental shelves off West Antarctica were investigated to depict recent sea surface and temperature conditions in this climate sensitive region. Proxy-based reconstructions of the sea surface conditions were compared to (1) satellite observations and (2) estimated sea-ice patterns and SSTs deduced from model data. The semi-quantitative sea-ice index PIPSO $_{25}$, combining the sea-ice proxy $\mathrm{IPSO}_{25}$ with an open-water phytoplankton marker, yielded reasonably good correlations with satellite observations and numerical model results, while correlations with the sea-ice proxy $\mathrm{IPSO}_{25}$ alone are rather low. Minimum concentrations of both biomarkers, used for the $\mathrm{PIPSO}_{25}$ calculations, however, may lead to ambiguous interpretations and significant underestimations of sea-ice conditions. The combination of different sea-ice measures when interpreting biomarker data should hence be strived for.

The presumed relationship between $\mathrm{IPSO}_{25}$ and platelet ice formation in connection to basal melting of ice shelves is supported by our data, showing high $\mathrm{IPSO}_{25}$ concentrations in areas where platelet ice formation has previously been reported and low $\mathrm{IPSO}_{25}$ concentrations where no platelet ice formation is occurring. Oceanic conditions and the intensity of basal melting, however, need to be considered when using $\mathrm{IPSO}_{25}$ as an indirect indicator for basal melting processes and associated ice shelf dynamics.

Temperature reconstructions based on $\mathrm{TEX}_{86}^{\mathrm{L}}$ and $\mathrm{RI}-\mathrm{OH}$ ' paleothermometers show similar patterns, but different absolute temperatures. While $\mathrm{TEX}^{\mathrm{L}}{ }_{86}$-derived temperatures are significantly warm-biased, the $\mathrm{RI}$-OH'-derived temperatures are proven 
more realistic, when compared to temperature data based on the WOA13 and modelled annual mean SSTs. Further investigations of HBI synthesis, transport, sedimentation and preservation within the sediments as well as the composition of its sources habitat (bottom ice, platelet ice, brine channels) and its connection to platelet ice formation via in situ or laboratory measurements are required to better constrain the proxy's potential as a robust sea-ice biomarker.

\section{Data availability}

Datasets related to this article can be found online on PANGAEA Data Publisher for Earth \& Environmental Science (doi: in 535 prep).

\section{Author contribution}

N.L. and J.M. designed the concept of the study. N.L. carried out biomarker experiments. X.S and G.L. developed the model code and X.S. performed the simulations. C.H. provided the satellite data. N.L. prepared the manuscript and visualizations with contributions from all co-authors.

\section{Competing interests}

The authors declare that they have no conflict of interest.

\section{Acknowledgements}

Denise Diekstall, Mandy Kuck and Jonas Haase are kindly acknowledged for laboratory support. We thank the captains, crews and science parties of RV Polarstern cruises PS69, PS97, PS104, PS111 and PS118. Especially Frank Niessen, Sabine Hanisch

545 and Michael Schreck are thanked for their support during PS118. Simon Belt is acknowledged for providing the 7-HND internal standard for HBI quantification. N.L., M.-E.V. and J.M. were funded through the Helmholtz Research Grant VH-NG1101.

\section{References}

Abernathey, R. P., Cerovecki, I., Holland, P. R., Newsom, E., Mazloff, M., and Talley, L. D.: Water-mass transformation by 550 sea ice in the upper branch of the Southern Ocean overturning, Nature Geoscience, 9, 596-601, 2016.

Allen, C. S., Pike, J., and Pudsey, C. J.: Last glacial-interglacial sea-ice cover in the SW Atlantic and its potential role in global deglaciation, Quaternary Science Reviews, 30, 2446-2458, 2011.

Alonso-Sáez, L., Andersson, A., Heinrich, F., and Bertilsson, S.: High archaeal diversity in Antarctic circumpolar deep waters, Environmental microbiology reports, 3, 689-697, 2011.

555 Anderson, P. S.: Evidence for an Antarctic winter coastal polynya, Antarctic science, 5, 221-226, 1993.

Armand, L. K., and Leventer, A.: Palaeo sea ice distribution-reconstruction and palaeoclimatic significance, Sea ice-an introduction to its physics, biology, chemistry, and geology, 333-372, 2003.

Arrigo, K. R., Worthen, D. L., Lizotte, M. P., Dixon, P., and Dieckmann, G.: Primary production in Antarctic sea ice, Science, 276, 394-397, 1997.

560 Arrigo, K. R.: Sea ice as a habitat for primary producers, Sea ice, 352-369, 2017.

Barbara, L., Crosta, X., Massé, G., and Ther, O.: Deglacial environments in eastern Prydz Bay, East Antarctica, Quaternary Science Reviews, 29, 2731-2740, 2010. 
Barbara, L., Crosta, X., Schmidt, S., and Massé, G.: Diatoms and biomarkers evidence for major changes in sea ice conditions prior the instrumental period in Antarctic Peninsula, Quaternary Science Reviews, 79, 99-110, 2013.

Belt, S. T., Allard, W. G., Massé, G., Robert, J.-M., and Rowland, S. J.: Highly branched isoprenoids (HBIs): identification of the most common and abundant sedimentary isomers, Geochimica et Cosmochimica Acta, 64, 3839-3851, 2000.

Belt, S. T., and Müller, J.: The Arctic sea ice biomarker $\mathrm{IP}_{25}$ : a review of current understanding, recommendations for future research and applications in palaeo sea ice reconstructions, Quaternary Science Reviews, 79, 9-25, 2013.

Belt, S. T., Brown, T. A., Ampel, L., Cabedo-Sanz, P., Fahl, K., Kocis, J. J., Masse, G., Navarro-Rodriguez, A., Ruan, J., and $\mathrm{Xu}, \mathrm{Y} .:$ An inter-laboratory investigation of the Arctic sea ice biomarker proxy $\mathrm{IP}_{25}$ in marine sediments: key outcomes and recommendations, Climate of the Past., 10, 155-166, 2014.

Belt, S. T., Cabedo-Sanz, P., Smik, L., Navarro-Rodriguez, A., Berben, S. M. P., Knies, J., and Husum, K.: Identification of paleo Arctic winter sea ice limits and the marginal ice zone: Optimised biomarker-based reconstructions of late Quaternary Arctic sea ice, Earth and Planetary Science Letters, 431, 127-139, 2015.

Belt, S. T., Smik, L., Brown, T. A., Kim, J. H., Rowland, S. J., Allen, C. S., Gal, J. K., Shin, K. H., Lee, J. I., and Taylor, K. W. R.: Source identification and distribution reveals the potential of the geochemical Antarctic sea ice proxy IPSO $_{25}, \mathrm{Nature}$ Communications, 7, 12655, https://doi.org/10.1038/ncomms12655, 2016.

Belt, S. T., Brown, T. A., Smik, L., Tatarek, A., Wiktor, J., Stowasser, G., Assmy, P., Allen, C. S., and Husum, K.: Identification of $\mathrm{C}_{25}$ highly branched isoprenoid (HBI) alkenes in diatoms of the genus Rhizosolenia in polar and sub-polar

580 marine phytoplankton, Organic Geochemistry, 110, 65-72, 2017.

Belt, S. T.: Source-specific biomarkers as proxies for Arctic and Antarctic sea ice, Organic Geochemistry, 125, 277-298, 2018.

Berger, A.: Long-term variations of daily insolation and Quaternary climatic changes, Journal of the atmospheric sciences, 35 , 2362-2367, 1978.

Boon, J. J., Rijpstra, W. I. C., de Lange, F., De Leeuw, J., Yoshioka, M., and Shimizu, Y.: Black Sea sterol—a molecular fossil for dinoflagellate blooms, Nature, 277, 125-127, 1979

Cavalieri, D., Parkinson, C., Gloersen, P., and Zwally, H.: Sea ice concentrations from Nimbus-7 SMMR and DMSP SSM/I passive microwave data, National Snow and Ice Data Center, Boulder, Colorado, USA, 1996.

Collares, L. L., Mata, M. M., Kerr, R., Arigony-Neto, J., and Barbat, M. M.: Iceberg drift and ocean circulation in the northwestern Weddell Sea, Antarctica, Deep Sea Research Part II: Topical Studies in Oceanography, 149, 10-24, 2018.

Colleoni, F., De Santis, L., Siddoway, C. S., Bergamasco, A., Golledge, N. R., Lohmann, G., Passchier, S., and Siegert, M. J.: Spatio-temporal variability of processes across Antarctic ice-bed-ocean interfaces, Nature Communications, 9, 2289, https://doi.org/10.1038/s41467-018-04583-0, 2018.

Collins, L. G., Allen, C. S., Pike, J., Hodgson, D. A., Weckström, K., and Massé, G.: Evaluating highly branched isoprenoid (HBI) biomarkers as a novel Antarctic sea-ice proxy in deep ocean glacial age sediments, Quaternary Science Reviews, 79,

$59587-98,2013$.

Comiso, J. C., Gersten, R. A., Stock, L. V., Turner, J., Perez, G. J., and Cho, K.: Positive Trend in the Antarctic Sea Ice Cover and Associated Changes in Surface Temperature, Journal of Climate, 30, 2251-2267, 2017.

Crosta, X., Pichon, J. J., and Burckle, L.: Application of modern analog technique to marine Antarctic diatoms: Reconstruction of maximum sea-ice extent at the Last Glacial Maximum, Paleoceanography and Paleoclimatology, 13, 284-297, 1998.

Danilov, S., Sidorenko, D., Wang, Q., and Jung, T.: The Finite-volumE Sea ice-Ocean Model (FESOM2), Geosci. Model Dev., 10, 765-789, 2017.

Deacon, G. R. E.: The Weddell Gyre, Deep Sea Research Part A. Oceanographic Research Papers, 26, 981-995, 1979.

Denis, D., Crosta, X., Barbara, L., Massé, G., Renssen, H., Ther, O., and Giraudeau, J.: Sea ice and wind variability during the Holocene in East Antarctica: insight on middle-high latitude coupling, Quaternary Science Reviews, 29, 3709-3719, 2010. 
Dorschel, B.: The Expedition PS118 of the Research Vessel POLARSTERN to the Weddell Sea in 2019, Berichte zur Polarund Meeresforschung = Reports on polar and marine research, 735, 2019.

Doty, M. S., and Oguri, M.: The island mass effect, ICES Journal of Marine Science, 22, 33-37, 1956.

Esper, O., and Gersonde, R.: New tools for the reconstruction of Pleistocene Antarctic sea ice, Palaeogeography, Palaeoclimatology, Palaeoecology, 399, 260-283, 2014.

610 Etourneau, J., Collins, L. G., Willmott, V., Kim, J.-H., Barbara, L., Leventer, A., Schouten, S., Damsté, J. S., Bianchini, A., and Klein, V.: Holocene climate variations in the western Antarctic Peninsula: evidence for sea ice extent predominantly controlled by changes in insolation and ENSO variability, Climate of the Past, 9, 1431-1446, 2013.

Fahl, K., and Stein, R.: Modern seasonal variability and deglacial/Holocene change of central Arctic Ocean sea-ice cover: new insights from biomarker proxy records, Earth and Planetary Science Letters, 351, 123-133, 2012.

615 Fetterer, F., Knowles, K., Meier, W., Savoie, M., Windnagel, A.K., 2016. Updated Daily. Sea Ice Index, Version 2. [Median Sea Ice Extent 1981-2010]. NSIDC: National Snow and Ice Data Center, Boulder, Colorado USA. https://doi.org/10.7265/N5736NV7 [24 July 2017].

Fietz, S., Huguet, C., Rueda, G., Hambach, B., and Rosell-Melé, A.: Hydroxylated isoprenoidal GDGTs in the Nordic Seas, Marine Chemistry, 152, 1-10, 2013.

620 Fietz, S., Ho, S., and Huguet, C.: Archaeal Membrane Lipid-Based Paleothermometry for Applications in Polar Oceans, Oceanography, 33, 104-114, 2020.

Foldvik, A., and Kvinge, T.: Conditional instability of sea water at the freezing point, Deep Sea Research and Oceanographic Abstracts, 21, 169-174, 1974.

Gersonde, R., and Zielinski, U.: The reconstruction of late Quaternary Antarctic sea-ice distribution — the use of diatoms as a

625 proxy for sea-ice, Palaeogeography, Palaeoclimatology, Palaeoecology, 162, 263-286, 2000.

Gohl, K.: The expedition ANTARKTIS-XXIII/4 of the research vessel Polarstern in 2006, Berichte zur Polar-und Meeresforschung (Reports on Polar and Marine Research), 557, 2007.

Gohl, K.: The Expedition PS104 of the Research Vessel POLARSTERN to the Amundsen Sea in 2017, Berichte zur Polarund Meeresforschung = Reports on polar and marine research, 712, 2017.

630 Hancke, K., Lund-Hansen, L. C., Lamare, M. L., Højlund Pedersen, S., King, M. D., Andersen, P., and Sorrell, B. K.: Extreme low light requirement for algae growth underneath sea ice: A case study from Station Nord, NE Greenland, Journal of Geophysical Research: Oceans, 123, 985-1000, 2018.

Harms, S., Fahrbach, E., and Strass, V. H.: Sea ice transports in the Weddell Sea, Journal of Geophysical Research: Oceans, 106, 9057-9073, 2001.

635 Ho, S. L., Mollenhauer, G., Fietz, S., Martínez-Garcia, A., Lamy, F., Rueda, G., Schipper, K., Méheust, M., Rosell-Melé, A., Stein, R., and Tiedemann, R.: Appraisal of $\mathrm{TEX}_{86}$ and thermometries in subpolar and polar regions, Geochimica et Cosmochimica Acta, 131, 213-226, 2014.

Hobbs, W. R., Massom, R., Stammerjohn, S., Reid, P., Williams, G., and Meier, W.: A review of recent changes in Southern Ocean sea ice, their drivers and forcings, Global and Planetary Change, 143, 228-250, 2016.

640 Holland, P. R., Feltham, D. L., and Jenkins, A.: Ice shelf water plume flow beneath Filchner-Ronne Ice Shelf, Antarctica, Journal of Geophysical Research: Oceans, 112, https://doi.org/10.1029/2006JC003915, 2007.

Hopmans, E. C., Weijers, J. W., Schefuß, E., Herfort, L., Damsté, J. S. S., and Schouten, S.: A novel proxy for terrestrial organic matter in sediments based on branched and isoprenoid tetraether lipids, Earth and Planetary Science Letters, 224, 107116, 2004.

645 Hoppmann, M., Nicolaus, M., Paul, S., Hunkeler, P. A., Heinemann, G., Willmes, S., Timmermann, R., Boebel, O., Schmidt, T., and Kühnel, M.: Ice platelets below Weddell Sea landfast sea ice, Annals of Glaciology, 56, 175-190, 2015. 
Hoppmann, M., Richter, M. E., Smith, I. J., Jendersie, S., Langhorne, P. J., Thomas, D. N., and Dieckmann, G. S.: Platelet ice, the Southern Ocean's hidden ice: a review, Annals of Glaciology, 1-28, 2020.

Huguet, C., de Lange, G. J., Gustafsson, Ö., Middelburg, J. J., Damsté, J. S. S., and Schouten, S.: Selective preservation of

soil organic matter in oxidized marine sediments (Madeira Abyssal Plain), Geochimica et Cosmochimica Acta, 72, 6061-6068, 2008.

Iacono, M. J., Delamere, J. S., Mlawer, E. J., Shephard, M. W., Clough, S. A., and Collins, W. D.: Radiative forcing by longlived greenhouse gases: Calculations with the AER radiative transfer models, Journal of Geophysical Research: Atmospheres, 113, https://doi.org/10.1029/2008JD009944, 2008.

655 Jacobs, S. S., Jenkins, A., Giulivi, C. F., and Dutrieux, P.: Stronger ocean circulation and increased melting under Pine Island Glacier ice shelf, Nature Geoscience, 4, 519-523, 2011.

Jenkins, A., and Jacobs, S.: Circulation and melting beneath George VI ice shelf, Antarctica, Journal of Geophysical Research: Oceans, 113, https://doi.org/10.1029/2007JC004449, 2008.

Johns, L., Wraige, E., Belt, S., Lewis, C., Massé, G., Robert, J.-M., and Rowland, S.: Identification of a $\mathrm{C}_{25}$ highly branched

660 isoprenoid (HBI) diene in Antarctic sediments, Antarctic sea-ice diatoms and cultured diatoms, Organic Geochemistry, 30, 1471-1475, 1999.

Kalanetra, K. M., Bano, N., and Hollibaugh, J. T.: Ammonia-oxidizing Archaea in the Arctic Ocean and Antarctic coastal waters, Environmental Microbiology, 11, 2434-2445, 2009.

Kim, J.-H., Van der Meer, J., Schouten, S., Helmke, P., Willmott, V., Sangiorgi, F., Koç, N., Hopmans, E. C., and Damsté, J.

665 S. S.: New indices and calibrations derived from the distribution of crenarchaeal isoprenoid tetraether lipids: Implications for past sea surface temperature reconstructions, Geochimica et Cosmochimica Acta, 74, 4639-4654, 2010.

Kim, J.-H., Crosta, X., Willmott, V., Renssen, H., Bonnin, J., Helmke, P., Schouten, S., and Sinninghe Damsté, J. S.: Holocene subsurface temperature variability in the eastern Antarctic continental margin, Geophysical Research Letters, 39, https://doi.org/10.1029/2012GL051157, 2012.

670 Klinck, J. M., Hofmann, E. E., Beardsley, R. C., Salihoglu, B., and Howard, S.: Water-mass properties and circulation on the west Antarctic Peninsula Continental Shelf in Austral Fall and Winter 2001, Deep Sea Research Part II: Topical Studies in Oceanography, 51, 1925-1946, 2004.

Köhler, P., Nehrbass-Ahles, C., Schmitt, J., Stocker, T. F., and Fischer, H.: A 156 kyr smoothed history of the atmospheric greenhouse gases $\mathrm{CO}_{2}, \mathrm{CH}_{4}$, and $\mathrm{N}_{2} \mathrm{O}$ and their radiative forcing, Earth Syst. Sci. Data, 9, 363-387, 2017.

675 Lamping, N., Müller, J., Esper, O., Hillenbrand, C.-D., Smith, J. A., and Kuhn, G.: Highly branched isoprenoids reveal onset of deglaciation followed by dynamic sea-ice conditions in the western Amundsen Sea, Antarctica, Quaternary Science Reviews, 228, https://doi.org/10.1016/j.quascirev.2019.106103, 2020.

Lange, M., Ackley, S., Wadhams, P., Dieckmann, G., and Eicken, H.: Development of sea ice in the Weddell Sea, Annals of Glaciology, 12, 92-96, 1989.

680 Langhorne, P., Hughes, K., Gough, A., Smith, I., Williams, M., Robinson, N., Stevens, C., Rack, W., Price, D., and Leonard, G.: Observed platelet ice distributions in Antarctic sea ice: An index for ocean-ice shelf heat flux, Geophysical Research Letters, 42, 5442-5451, 2015.

Leventer, A.: The fate of Antarctic "sea ice diatoms" and their use as paleoenvironmental indicators, Antarctic sea ice. Biological processes, interactions and variability, 121-137, 1998.

685 Liu, J., Curry, J. A., and Martinson, D. G.: Interpretation of recent Antarctic sea ice variability, Geophysical Research Letters, 31, https://doi.org/10.1029/2003GL018732, 2004.

Locarnini, R. A., Mishonov, A. V., Antonov, J. I., Boyer, T. P., Garcia, H. E., Baranova, O. K., Zweng, M. M., Paver, C. R., Reagan, J. R., and Johnson, D. R.: World ocean atlas 2013. Volume 1, Temperature, NOAA Atlas NESDIS 73, 40 pp., doi: 10.7289/V55X26VD, 2013. 
690 Lohmann, G., Butzin, M., Eissner, N., Shi, X., and Stepanek, C.: Abrupt climate and weather changes across time scales, Paleoceanography and Paleoclimatology, 35, https://doi.org/10.1029/2019PA003782, 2020.

López-García, P., Rodriguez-Valera, F., Pedrós-Alió, C., and Moreira, D.: Unexpected diversity of small eukaryotes in deepsea Antarctic plankton, Nature, 409, 603-607, 2001.

Lorenz, S. J., and Lohmann, G.: Acceleration technique for Milankovitch type forcing in a coupled atmosphere-ocean circulation model: method and application for the Holocene, Climate Dynamics, 23, 727-743, 2004.

Lott, F.: Alleviation of stationary biases in a GCM through a mountain drag parameterization scheme and a simple representation of mountain lift forces, Monthly weather review, 127, 788-801, 1999.

Loveland, T. R., Reed, B. C., Brown, J. F., Ohlen, D. O., Zhu, Z., Yang, L., and Merchant, J. W.: Development of a global land cover characteristics database and IGBP DISCover from 1 km AVHRR data, Int. J. Remote Sens., 21, 1303-1330, 2000.

700 Lü, X., Liu, X.-L., Elling, F. J., Yang, H., Xie, S., Song, J., Li, X., Yuan, H., Li, N., and Hinrichs, K.-U.: Hydroxylated isoprenoid GDGTs in Chinese coastal seas and their potential as a paleotemperature proxy for mid-to-low latitude marginal seas, Organic Geochemistry, 89-90, 31-43, 2015.

Massé, G., Belt, S. T., Crosta, X., Schmidt, S., Snape, I., Thomas, D. N., and Rowland, S. J.: Highly branched isoprenoids as proxies for variable sea ice conditions in the Southern Ocean, Antarctic Science, 23, 487-498, 2011.

705 Massom, R. A., Scambos, T. A., Bennetts, L. G., Reid, P., Squire, V. A., and Stammerjohn, S. E.: Antarctic ice shelf disintegration triggered by sea ice loss and ocean swell, Nature, 558, 383-389, 2018.

Medlin, L.: Berkeleya spp. from Antarctic waters, including Berkeleya adeliensis, sp. nov., a new tube dwelling diatom from the undersurface of sea-ice, Beihefte zur Nova Hedwigia, 100, 77-89, 1990.

Meredith, M. P., Woodworth, P. L., Chereskin, T. K., Marshall, D. P., Allison, L. C., Bigg, G. R., Donohue, K., Heywood, K.

710 J., Hughes, C. W., and Hibbert, A.: Sustained monitoring of the Southern Ocean at Drake Passage: Past achievements and future priorities, Reviews of Geophysics, 49, https://doi.org/10.1029/2010RG000348, 2011.

Meyers, P. A.: Organic geochemical proxies of paleoceanographic, paleolimnologic, and paleoclimatic processes, Organic geochemistry, 27, 213-250, 1997.

Moore, J. K., and Abbott, M. R.: Surface chlorophyll concentrations in relation to the Antarctic Polar Front: seasonal and

715 spatial patterns from satellite observations, Journal of Marine Systems, 37, 69-86, 2002.

Müller, J., Wagner, A., Fahl, K., Stein, R., Prange, M., and Lohmann, G.: Towards quantitative sea ice reconstructions in the northern North Atlantic: A combined biomarker and numerical modelling approach, Earth and Planetary Science Letters, 306, 137-148, 2011.

Müller, J., and Stein, R.: High-resolution record of late glacial and deglacial sea ice changes in Fram Strait corroborates iceocean interactions during abrupt climate shifts, Earth and Planetary Science Letters, 403, 446-455, 2014.

Nicholls, K. W., Østerhus, S., Makinson, K., Gammelsrød, T., and Fahrbach, E.: Ice-ocean processes over the continental shelf of the southern Weddell Sea, Antarctica: A review, Reviews of Geophysics, 47, https://doi.org/10.1029/2007RG000250, 2009. Nichols, P. D., Palmisano, A. C., Volkman, J. K., Smith, G. A., and White, D. C.: Occurrence of an isoprenoid $\mathrm{C}_{25}$ diunasaturated alkene and high neutral lipid content in Antarctic sea-ice diatom communities 1, Journal of Phycology, 24, 90-

$72596,1988$.

Nielsdóttir, M. C., Bibby, T. S., Moore, C. M., Hinz, D. J., Sanders, R., Whitehouse, M., Korb, R., and Achterberg, E. P.: Seasonal and spatial dynamics of iron availability in the Scotia Sea, Marine Chemistry, 130, 62-72, 2012.

Nolting, R., De Baar, H., Van Bennekom, A., and Masson, A.: Cadmium, copper and iron in the Scotia Sea, Weddell Sea and Weddell/Scotia confluence (Antarctica), Marine Chemistry, 35, 219-243, 1991.

730 Orsi, A. H., Whitworth III, T., and Nowlin Jr, W. D.: On the meridional extent and fronts of the Antarctic Circumpolar Current, Deep Sea Research Part I: Oceanographic Research Papers, 42, 641-673, 1995. 
Otto-Bliesner, B., Brady, E., Zhao, A., Brierley, C., Axford, Y., Capron, E., Govin, A., Hoffman, J., Isaacs, E., and Kageyama, M.: Large-scale features of Last Interglacial climate: Results from evaluating the lig127k simulations for CMIP6-PMIP4, Climate of the Past, 17, 63-94, 2021.

735 Otto-Bliesner, B. L., Braconnot, P., Harrison, S. P., Lunt, D. J., Abe-Ouchi, A., Albani, S., Bartlein, P. J., Capron, E., Carlson, A. E., and Dutton, A.: The PMIP4 contribution to CMIP6-Part 2: Two interglacials, scientific objective and experimental design for Holocene and Last Interglacial simulations, Geoscientific Model Development, 10, 3979-4003, 2017.

Park, E., Hefter, J., Fischer, G., Iversen, M. H., Ramondenc, S., Nöthig, E.-M., and Mollenhauer, G.: Seasonality of archaeal lipid flux and GDGT-based thermometry in sinking particles of high-latitude oceans: Fram Strait $\left(79^{\circ} \mathrm{N}\right)$ and Antarctic Polar Front (50 S), Biogeosciences, 16, 2247-2268, 2019.

Parkinson, C. L., and Cavalieri, D. J.: Antarctic sea ice variability and trends, 1979-2010, The Cryosphere, 6, 871-880, 2012. Parkinson, C. L.: A 40-y record reveals gradual Antarctic sea ice increases followed by decreases at rates far exceeding the rates seen in the Arctic, Proceedings of the National Academy of Sciences, 116, 14414-14423, 2019.

Paul, S., Willmes, S., and Heinemann, G.: Long-term coastal-polynya dynamics in the southern Weddell Sea from MODIS

745 thermal-infrared imagery, The Cryosphere, 9, 2027-2041, 2015.

Pritchard, H., Ligtenberg, S., Fricker, H., Vaughan, D., Van den Broeke, M., and Padman, L.: Antarctic ice-sheet loss driven by basal melting of ice shelves, Nature, 484, 502-505, 2012.

Raddatz, T., Reick, C., Knorr, W., Kattge, J., Roeckner, E., Schnur, R., Schnitzler, K.-G., Wetzel, P., and Jungclaus, J.: Will the tropical land biosphere dominate the climate-carbon cycle feedback during the twenty-first century?, Climate dynamics, 29, 565-574, 2007.

Riaux-Gobin, C., and Poulin, M.: Possible symbiosis of Berkeleya adeliensis Medlin, Synedropsis fragilis (Manguin) Hasle et al. and Nitzschia lecointei Van Heurck (Bacillariophyta) associated with land-fast ice in Adélie Land, Antarctica, Diatom Research, 19, 265-274, 2004.

Riaux-Gobin, C., Dieckmann, G. S., Poulin, M., Neveux, J., Labrune, C., and Vetion, G.: Environmental conditions, particle

755 flux and sympagic microalgal succession in spring before the sea-ice break-up in Adélie Land, East Antarctica, Polar Research, 32, https://doi.org/10.3402/polar.v32i0.19675, 2013.

Rintoul, S., Hughes, C., and Olbers, D.: The Antarctic circumpolar current system, International Geophysics, 77, 271-302, 2001.

Roeckner, E., Dümenil, L., Kirk, E., Lunkeit, F., Ponater, M., Rockel, B., Sausen, R., and Schlese, U.: The Hamburg version of the ECMWF model (ECHAM), Research activities in atmospheric and oceanic modelling. CAS/JSC Working Group on Numerical Experimentation, 13, 7.1-7.4, 1989.

Sangrà, P., Gordo, C., Hernández-Arencibia, M., Marrero-Díaz, A., Rodríguez-Santana, A., Stegner, A., Martínez-Marrero, A., Pelegrí, J. L., and Pichon, T.: The Bransfield current system, Deep Sea Research Part I: Oceanographic Research Papers, 58, 390-402, 2011.

765 Scambos, T. A., Bell, R. E., Alley, R. B., Anandakrishnan, S., Bromwich, D., Brunt, K., Christianson, K., Creyts, T., Das, S., and DeConto, R.: How much, how fast?: A science review and outlook for research on the instability of Antarctica's Thwaites Glacier in the 21st century, Global and Planetary Change, 153, 16-34, 2017.

Schmidt, K., Brown, T. A., Belt, S. T., Ireland, L. C., Taylor, K. W., Thorpe, S. E., Ward, P., and Atkinson, A.: Do pelagic grazers benefit from sea ice? Insights from the Antarctic sea ice proxy $\mathrm{IPSO}_{25}, 15,1987-2006,2018$.

770 Schmidtko, S., Heywood, K. J., Thompson, A. F., and Aoki, S.: Multidecadal warming of Antarctic waters, Science, 346, 1227-1231, 2014.

Schofield, O., Brown, M., Kohut, J., Nardelli, S., Saba, G., Waite, N., and Ducklow, H.: Changes in the upper ocean mixed layer and phytoplankton productivity along the West Antarctic Peninsula, Philosophical Transactions of the Royal Society A: Mathematical, Physical and Engineering Sciences, 376, https://doi.org/10.1098/rsta.2017.0173, 2018. 

membrane lipids: a new tool for reconstructing ancient sea water temperatures?, Earth and Planetary Science Letters, 204, 265-274, 2002.

Schouten, S., Hopmans, E. C., and Sinninghe Damsté, J. S.: The organic geochemistry of glycerol dialkyl glycerol tetraether lipids: A review, Organic Geochemistry, 54, 19-61, 2013.

Schröder, M.: The Expedition PS111 of the Research POLARSTERN to the southern Weddell Sea in 2018, Berichte zur Polarund Meeresforschung = Reports on polar and marine research, 718, 2018.

Sidorenko, D., Goessling, H., Koldunov, N., Scholz, P., Danilov, S., Barbi, D., Cabos, W., Gurses, O., Harig, S., and Hinrichs, C.: Evaluation of FESOM2. 0 coupled to ECHAM6. 3: Preindustrial and HighResMIP simulations, Journal of Advances in Modeling Earth Systems, 11, 3794-3815, 2019.

785 Smik, L., Belt, S. T., Lieser, J. L., Armand, L. K., and Leventer, A.: Distributions of highly branched isoprenoid alkenes and other algal lipids in surface waters from East Antarctica: further insights for biomarker-based paleo sea-ice reconstruction, Organic Geochemistry, 95, 71-80, 2016.

Spencer-Jones, C. L., McClymont, E. L., Bale, N. J., Hopmans, E. C., Schouten, S., Müller, J., Abrahamsen, E. P., Allen, C., Bickert, T., Hillenbrand, C. D., Mawbey, E., Peck, V., Svalova, A., and Smith, J. A.: Archaeal Intact Polar Lipids in Polar Waters: A Comparison Between the Amundsen and Scotia Seas, Biogeosciences Discuss. [preprint], https://doi.org/10.5194/bg-2020-333, in review, 2020.

Stevens, B., Giorgetta, M., Esch, M., Mauritsen, T., Crueger, T., Rast, S., Salzmann, M., Schmidt, H., Bader, J., and Block, K.: Atmospheric component of the MPI-M Earth system model: ECHAM6, Journal of Advances in Modeling Earth Systems, 5, 146-172, 2013.

795 Stocker, T. F., Qin, D., Plattner, G.-K., Tignor, M., Allen, S. K., Boschung, J., Nauels, A., Xia, Y., Bex, V., and Midgley, P. M.: The physical science basis. Contribution of working group I to the fifth assessment report of the intergovernmental panel on climate change, Computational Geometry, 18, 95-123, 2013.

Tesi, T., Belt, S., Gariboldi, K., Muschitiello, F., Smik, L., Finocchiaro, F., Giglio, F., Colizza, E., Gazzurra, G., and Giordano, P.: Resolving sea ice dynamics in the north-western Ross Sea during the last 2.6 ka: From seasonal to millennial timescales,

Quaternary Science Reviews, 237, http://dx.doi.org/10.1016/j.quascirev.2020.106299, 2020.

Thomas, D. N.: Sea ice, John Wiley \& Sons, 2017.

Thompson, A. F., Heywood, K. J., Thorpe, S. E., Renner, A. H., and Trasviña, A.: Surface circulation at the tip of the Antarctic Peninsula from drifters, Journal of Physical Oceanography, 39, 3-26, 2009.

Thompson, A. F., Stewart, A. L., Spence, P., and Heywood, K. J.: The Antarctic Slope Current in a changing climate, Reviews 805 of Geophysics, 56, 741-770, 2018.

Turner, J., Orr, A., Gudmundsson, G. H., Jenkins, A., Bingham, R. G., Hillenbrand, C.-D., and Bracegirdle, T. J.: Atmosphereocean-ice interactions in the Amundsen Sea Embayment, West Antarctica, Reviews of Geophysics, 55, 235-276, 2017.

Valcke, S.: The OASIS3 coupler: A European climate modelling community software, Geoscientific Model Development, 6, 373-388, 2013.

810 Vaughan, D. G., Marshall, G. J., Connolley, W. M., Parkinson, C., Mulvaney, R., Hodgson, D. A., King, J. C., Pudsey, C. J., and Turner, J.: Recent rapid regional climate warming on the Antarctic Peninsula, Climatic change, 60, 243-274, 2003.

Vaughan, D. G.: West Antarctic Ice Sheet collapse-the fall and rise of a paradigm, Climatic Change, 91, 65-79, 2008.

Vernet, M., Geibert, W., Hoppema, M., Brown, P. J., Haas, C., Hellmer, H., Jokat, W., Jullion, L., Mazloff, M., and Bakker, D.: The Weddell Gyre, Southern Ocean: present knowledge and future challenges, Reviews of Geophysics, 57, 623-708, 2019.

815 Volkman, J. K.: Lipid markers for marine organic matter, in: Marine organic matter: Biomarkers, isotopes and DNA, Springer, 27-70, 2006. 
Vorrath, M.-E., Müller, J., Esper, O., Mollenhauer, G., Haas, C., Schefuß, E., and Fahl, K.: Highly branched isoprenoids for Southern Ocean sea ice reconstructions: a pilot study from the Western Antarctic Peninsula, Biogeosciences, 16, 2961-2981, 2019.

820 Vorrath, M.-E., Müller, J., Rebolledo, L., Cárdenas, P., Shi, X., Esper, O., Opel, T., Geibert, W., Muñoz, P., and Haas, C.: Sea ice dynamics in the Bransfield Strait, Antarctic Peninsula, during the past 240 years: a multi-proxy intercomparison study, Climate of the Past, 16, 2459-2483, 2020.

Xiao, X., Fahl, K., Müller, J., and Stein, R.: Sea-ice distribution in the modern Arctic Ocean: Biomarker records from transArctic Ocean surface sediments, Geochimica et Cosmochimica Acta, 155, 16-29, 2015.

825 Zamelczyk, K., Rasmussen, T. L., Husum, K., Haflidason, H., de Vernal, A., Ravna, E. K., Hald, M., and Hillaire-Marcel, C.: Paleoceanographic changes and calcium carbonate dissolution in the central Fram Strait during the last 20 ka, Quaternary Research, 78, 405-416, 2012.

Zielinski, U., Gersonde, R., Sieger, R., and Fütterer, D.: Quaternary surface water temperature estimations: Calibration of a diatom transfer function for the Southern Ocean, Paleoceanography and Paleoclimatology, 13, 365-383, 1998.

830 Zwally, H. J.: Antarctic sea ice, 1973-1976: Satellite passive-microwave observations, Scientific and Technical Information Branch, National Aeronautics and Space, 1983 


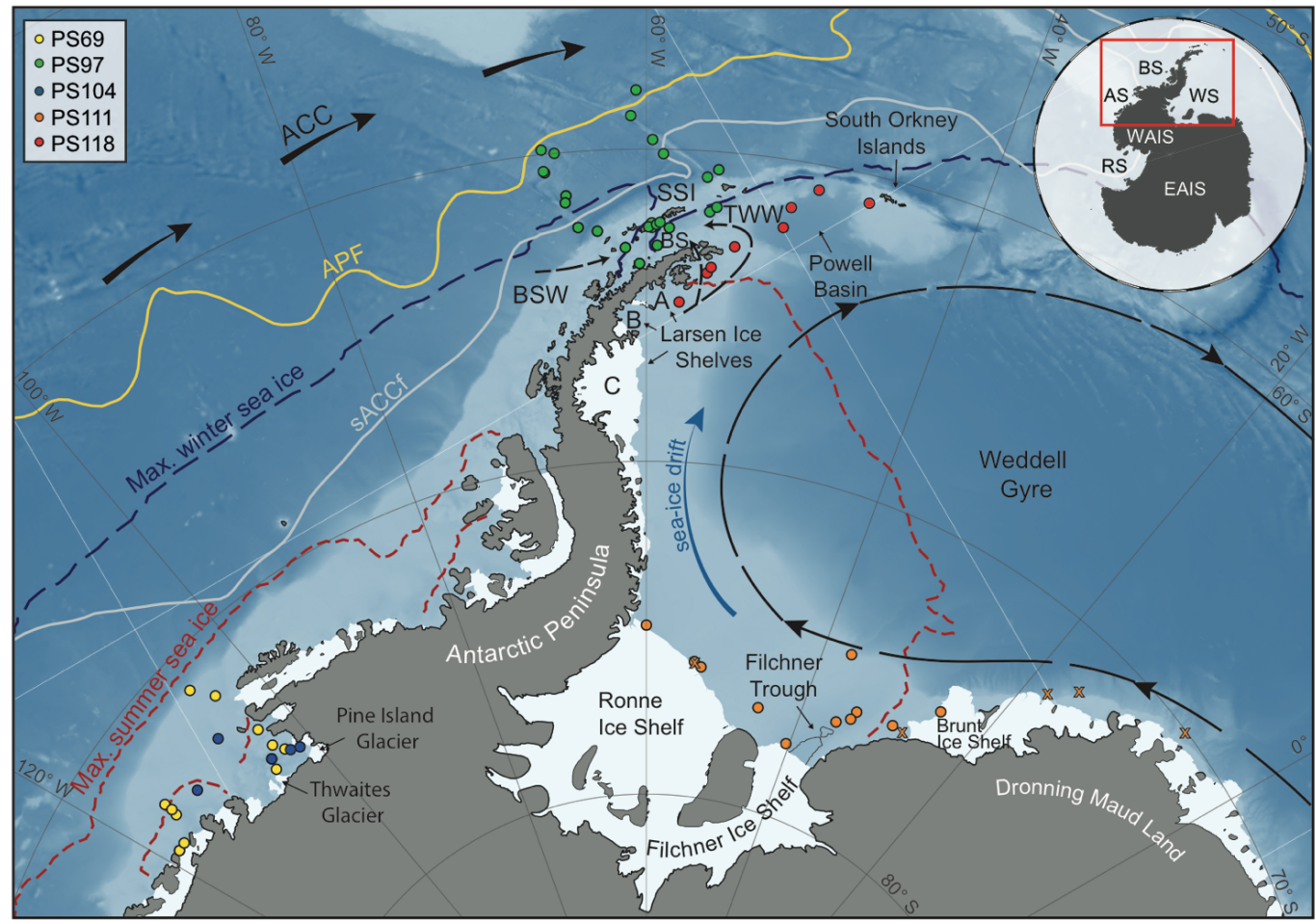

Fig. 1: Map of the study area (location indicated by red box in insert map) including all 41 sample locations (see different colored dots for individual FS Polarstern expeditions in the top left corner; for detailed sample information see Table S1) and main oceanographic features. Max. summer and winter sea-ice boundaries are marked by dashed red and blue line, respectively (Fetterer et al., 2016). Orange crosses indicate samples where a PIPSO $_{25}$ value of 1 has been assigned due to low biomarker concentrations, close to detection limit. ACC: Antaretic Circumpolar Current, APF: Antarctic Polar Front, sACCf: southern Antarctic Circumpolar Current Front, SSI: South Shetland Islands, BS: Bransfield Strait, BSW: Bellingshausen Sea Water, TWW: Transitional Weddell Sea Water (Mathiot et al., 2011; Orsi et al., 1995). Insert map shows grounded ice only (i.e., no ice shelves), WAIS: West Antarctic Ice Sheet, EAIS: East Antarctic Ice Sheet, RS: Ross Sea, AS: Amundsen Sea, BS: Bellingshausen Sea, WS: Weddell Sea. Background bathymetry derived from IBCSO data (Arndt et al., 2013).
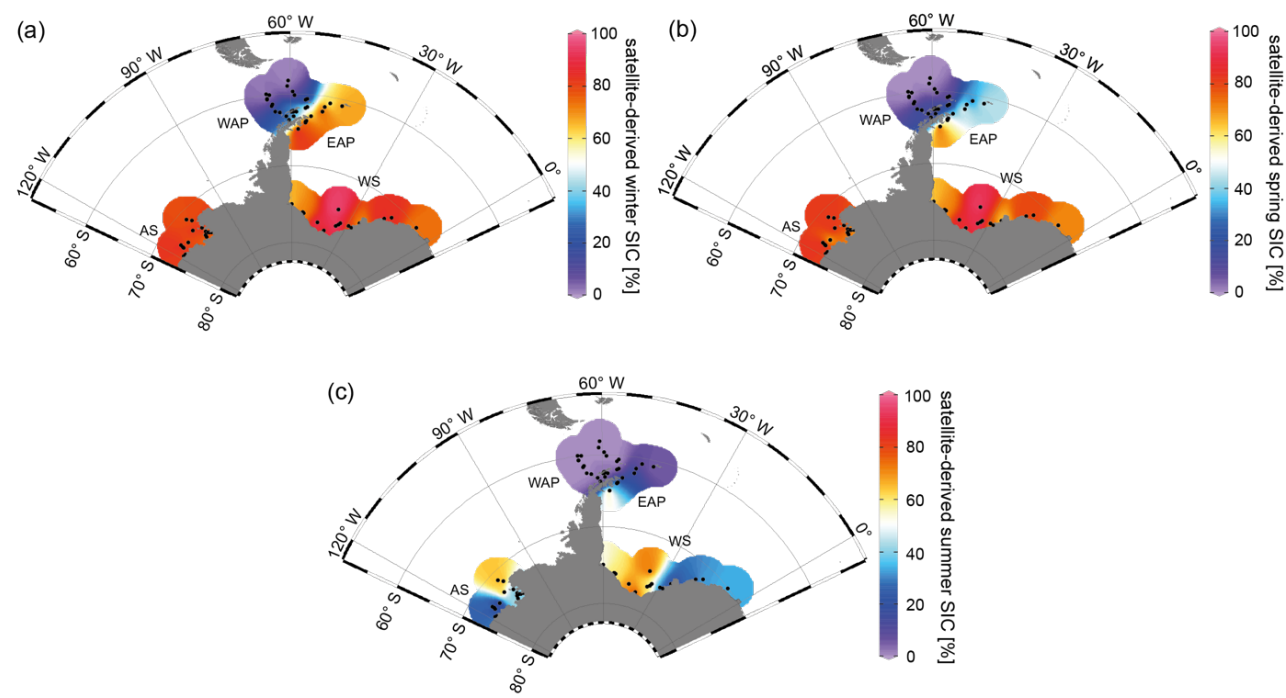

Fig. 2: Distribution of mean monthly satellite-derived sea-ice concentrations for (a) winter (JJA), (b) spring (SON) and (c) summer (DJF) in \% (downloaded from the National Snow and Ice Data Center, NSIDC; Cavalieri et al., 1996). AS: Amundsen Sea, WAP: West Antarctic Peninsula, EAP: East Antarctic Peninsula, WS: Weddell Sea. 

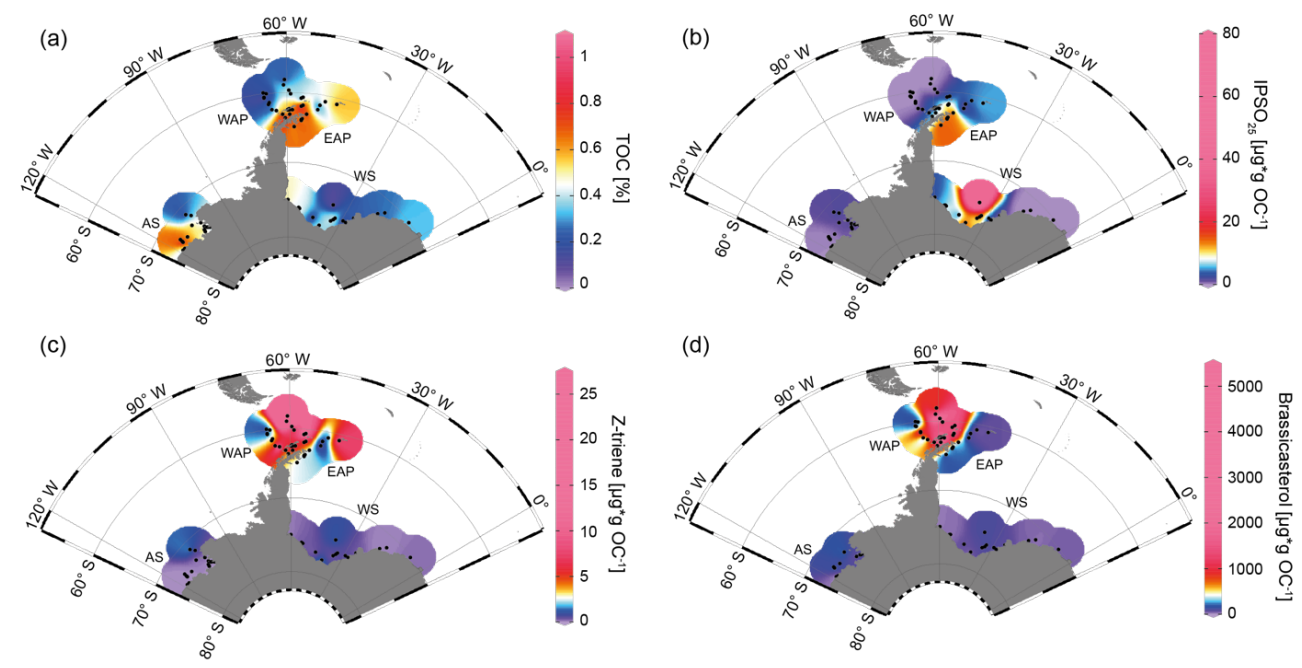

Fig. 3: Distribution of (a) TOC [\%], (b) IPSO $_{25}$, (c) Z-triene and (d) brassicasterol in surface sediment samples. Sample locations are marked as black dots. Concentrations of biomarkers $\left[\mu \mathrm{g}^{*} \mathrm{~g} \mathrm{OC}^{-1}\right]$ were normalized to the TOC content of each sample. AS: Amundsen Sea, WAP: West Antarctic Peninsula, EAP: East Antarctic Peninsula, WS: Weddell Sea.
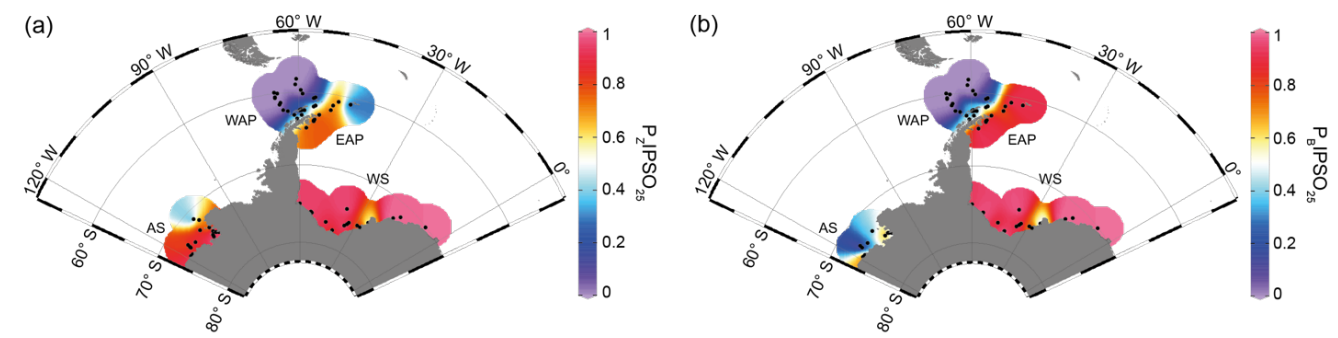

Fig. 4: Distribution of the sea-ice index PIPSO $_{25}$ in surface sediment samples, with (a) $\mathbf{P}_{\mathrm{Z}} \mathrm{PSO}_{25}$ based on $\mathrm{Z}$-triene and (b) $P_{\mathrm{B}}$ IPSO $_{25}$ based on brassicasterol. AS: Amundsen Sea, WAP: West Antarctic Peninsula, EAP: East Antarctic Peninsula, WS: Weddell Sea. 
(a)

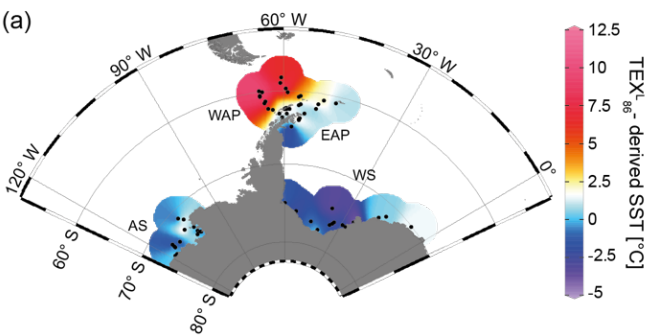

(c)

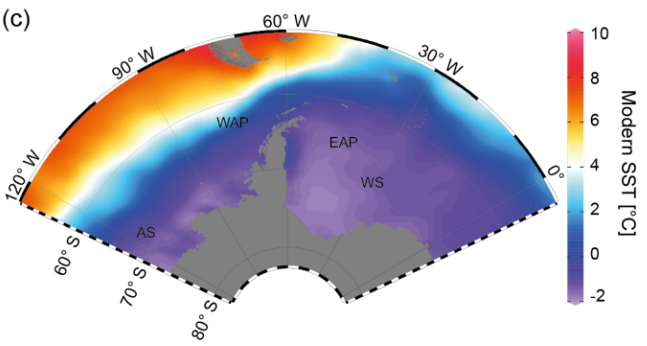

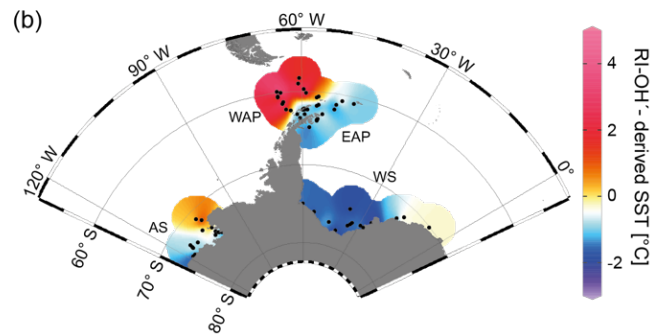

(d)

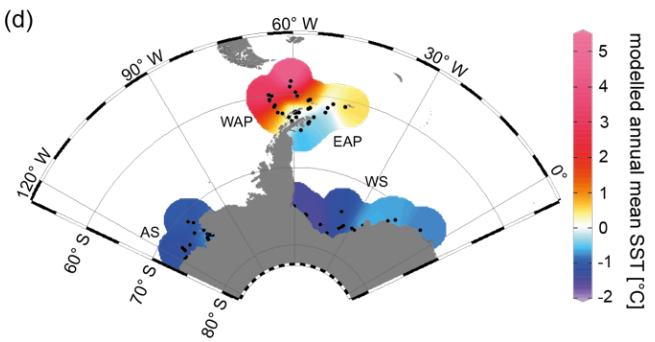

Fig. 5: Annual mean temperature distributions derived from (a) $\mathrm{TEX}^{\mathrm{L}}{ }_{86}$, (b) RI-OH', (c) WOA13 (Locarnini et al., 2013 ) and (d) model data in ${ }^{\circ} \mathrm{C}$. AS: Amundsen Sea, WAP: West Antarctic Peninsula, EAP: East Antarctic Peninsula, WS: Weddell Sea.
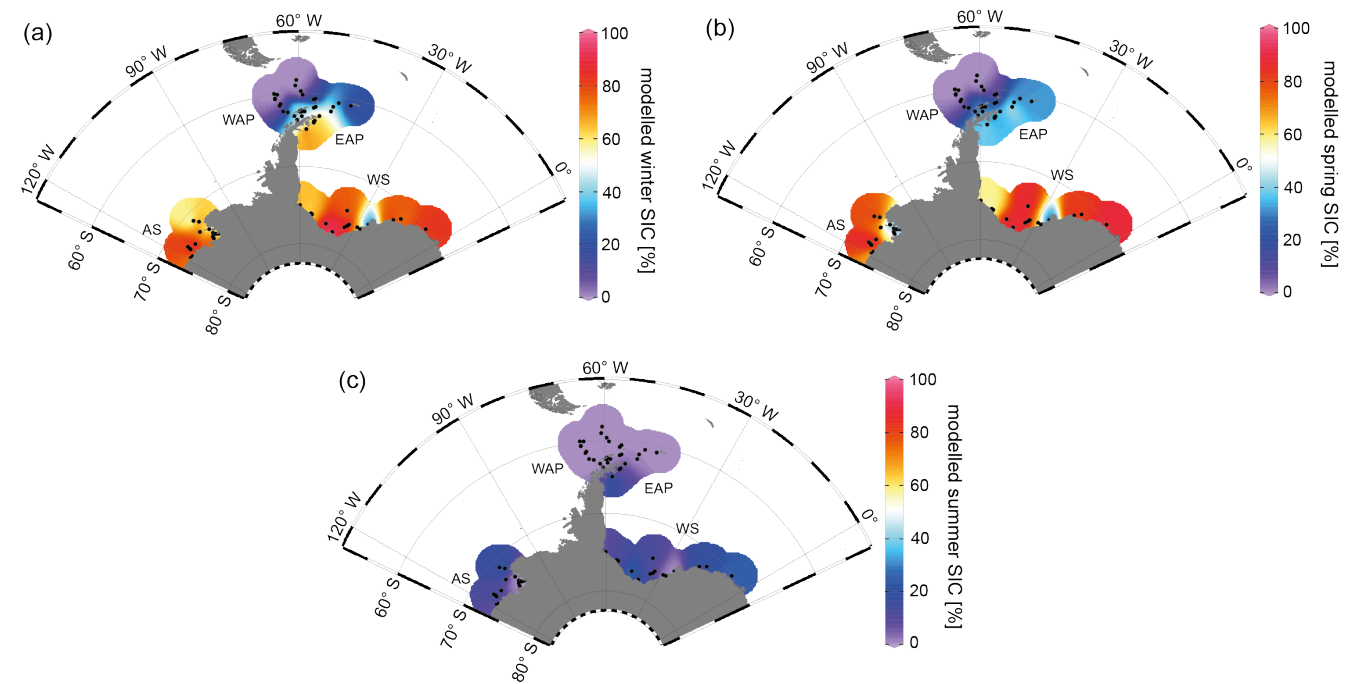

Fig. 6: Modelled SIC for (a) winter (JJA), (b) spring (SON) and (c) summer (DJF) in \%. AS: Amundsen Sea, WAP: West Antarctic Peninsula, EAP: East Antarctic Peninsula, WS: Weddell Sea 
https://doi.org/10.5194/cp-2021-19

Preprint. Discussion started: 1 March 2021

(c) Author(s) 2021. CC BY 4.0 License.

(a)

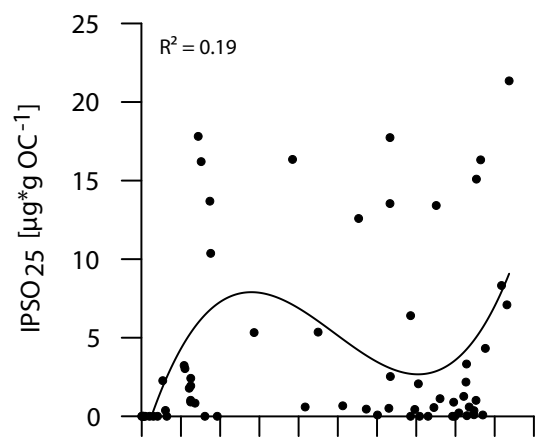

0102030405060708090100

Spring satellite SIC [\%]

(c)

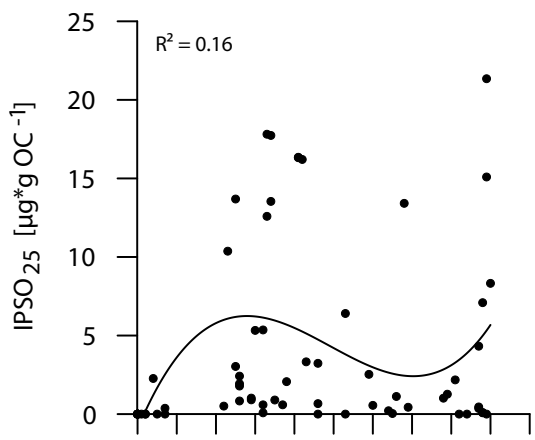

0102030405060708090100

Modelled spring SIC [\%] AWIESM2 (b)

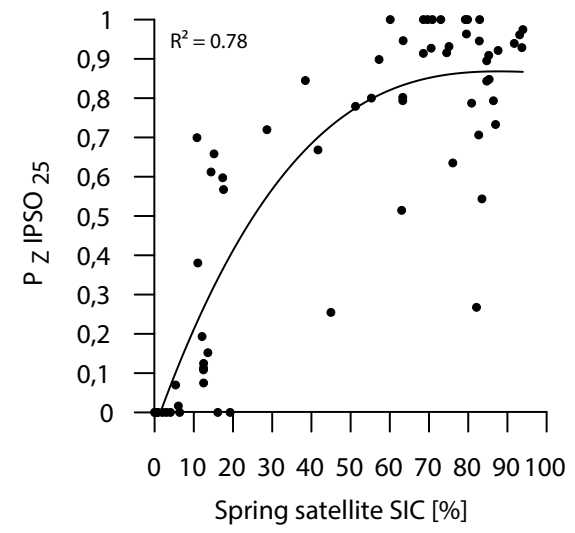

(d)

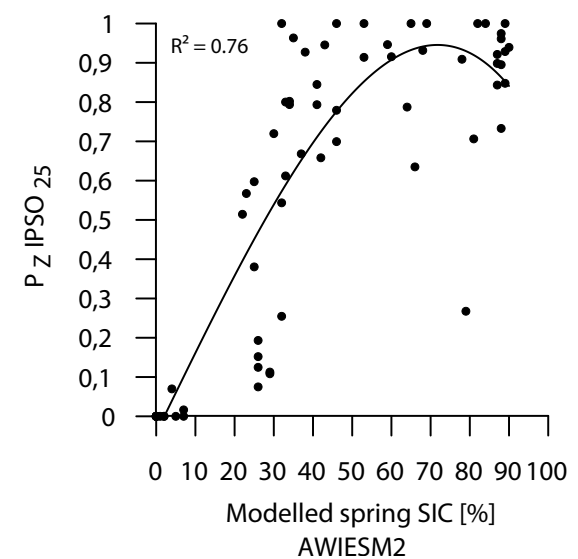

Fig. 7: Correlations of (a) IPSO $_{25}$ concentrations vs. spring satellite SIC, (b) P $_{Z}$ IPSO $_{25}$ values vs. spring satellite SIC, (c) IPSO ${ }_{25}$ concentrations vs. modelled spring SIC and (d) $\mathbf{P}_{Z}$ IPSO ${ }_{25}$ values vs. modelled spring SIC. Coefficients of determination ( $R^{2}$ ) are given for the respective regression lines.

(a)

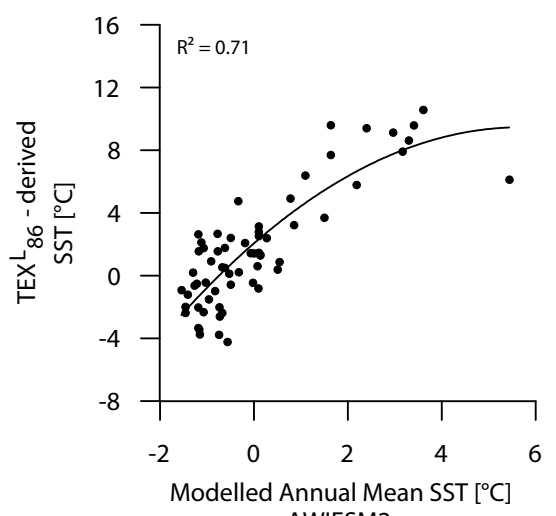

AWIESM2 (b)

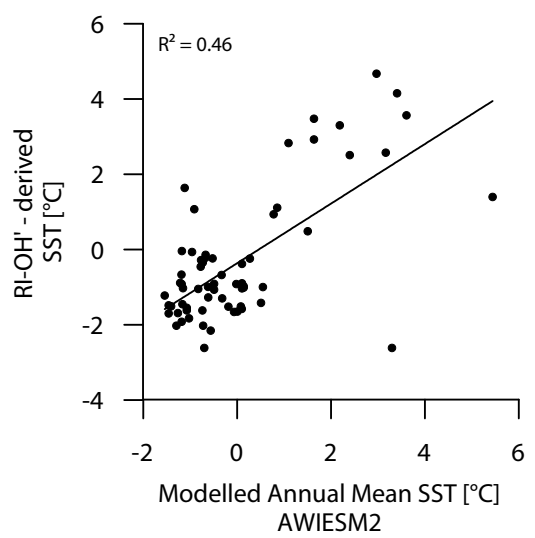

Fig. 8: Correlations of (a) $\mathrm{TEX}^{\mathrm{L}}{ }_{86}$-derived temperatures vs. modelled annual mean SSTs and (b) RI-OH'-derived temperatures vs. modelled annual mean SSTs. Coefficients of determination $\left(R^{2}\right)$ are given for the respective regression lines. 
https://doi.org/10.5194/cp-2021-19

Climate

Preprint. Discussion started: 1 March 2021

(c) Author(s) 2021. CC BY 4.0 License.

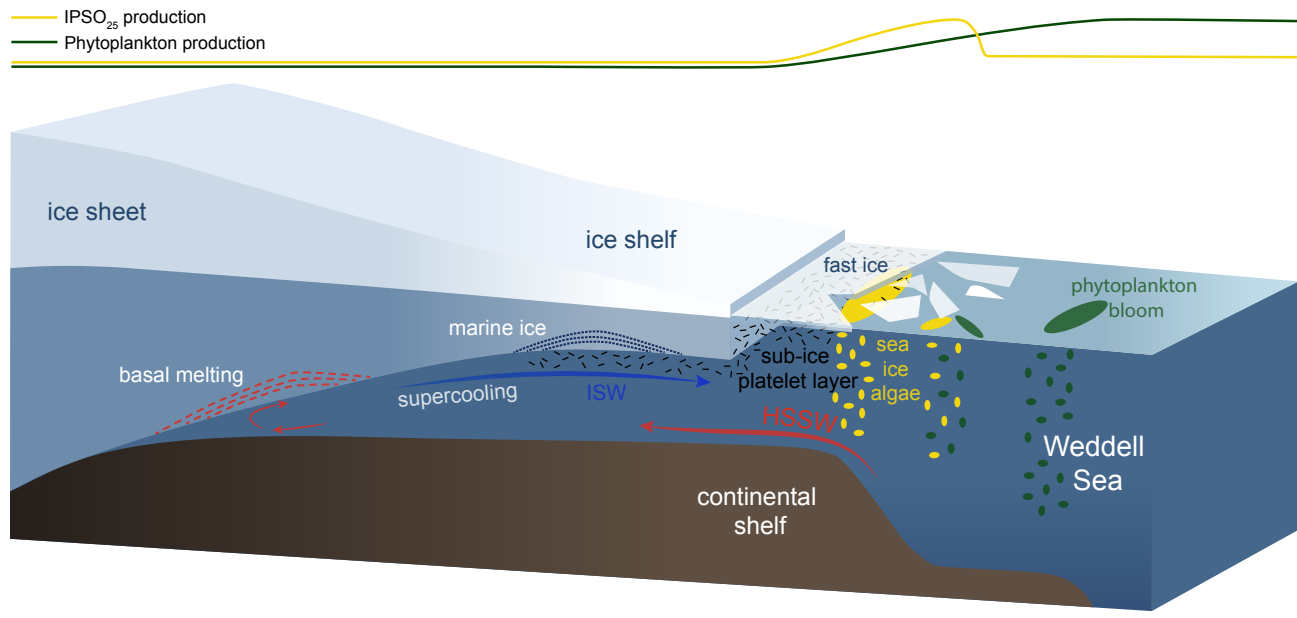

Fig. 9: Schematic illustration of the formation of platelet ice and the main production areas of sea ice algae producing IPSO ${ }_{25}$ (yellow ovals) and phytoplankton (green ovals), also displayed by yellow and green curves at the top. HSSW: High Saline Shelf Water, ISW: Ice Shelf Water. Schematic modified after Scambos et al. (2017). 